\title{
A multilingual corpus approach to postpredicativity in spoken Turkish, Kurmanji Kurdish and German
}

\author{
Annette Herkenrath*
}

\begin{abstract}
This paper investigates phenomena of postpredicativity in a TurkishKurmanji Kurdish-German trilingual corpus of spoken language. Starting from the assumption that postpredicativity when viewed in this trilingual perspective is an epiphenomenal effect of argument type in Kurmanji, finite verb movement in German and discourse activation status (next to illocutionarily motivated verb fronting) in Turkish, it sets out to explore overlaps and double motivations. Based on a collection of 1,211 findings, differentiations within the categories as well as overlaps at several levels are identified. Central results are discourse-level motivations in Kurmanji, their dependence on syntactic size, and overlaps between illocutional verb fronting and discourse activation status in Turkish.
\end{abstract}

Keywords. Syntax, postpredicativity, Turkish, Kurmanji Kurdish, German, spoken language, argument structure, verb fronting, discourse activation, categorial overlaps.

1. Introduction. This paper investigates post-predicativity in a trilingual contact situation involving Turkish, Kurmanji Kurdish ${ }^{1}$ and German, on the basis of a multilingual corpus of spoken language collected as free-flowing narratives in a diasporic context, under construction (some ten hours of transcribed recordings so far, Herkenrath in preparation a, b, c). Post-predicative elements are NPs or other elements that appear after the predicate of a sentence or an utterance; see example (1):

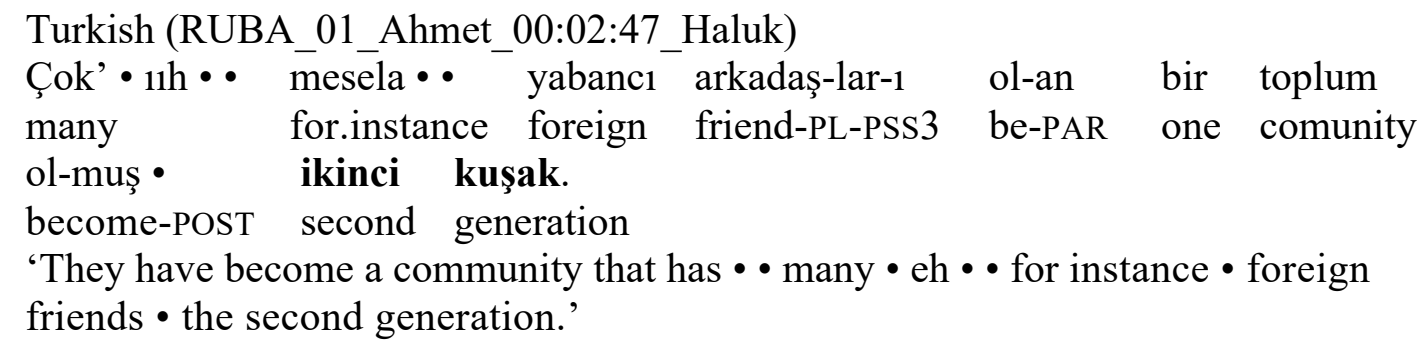

\footnotetext{
* Earlier versions of this study received input and discussion from the Workshop on postverbal structures (Turkish, Turkic, + language contact), organised by Elisabetta Ragagnin, Christoph Schroeder and Kateryna Iefremenko, December 14, 2019, at the Department of Turcology of the Free University of Berlin, and the 6th Workshop on Turkic Languages and Languages in Contact with Turkic organised by the University of Toronto Department of Linguistics, February 19-20, 2021, held online; I wish to thank the organisers and the audience. Two anonymous reviewers provided helpful suggestions. Collection of part of the data used in this study took place within the framework of the LiLaC project, 'Literacy between Languages and Cultures', 2007-2010, sponsored by the Volkswagen Foundation and supervised by Professor Ludger Hoffmann, Professor Uta Quasthoff and Professor Michael Kastner, TU Dortmund University, Departments of German and of Psychology. Above all, I wish to thank the anonymous participants in the recordings for sharing their experiences and ideas. Author: Annette Herkenrath, Uniwersytet im. Adama Mickiewicza w Poznaniu/ (annher3@amu.edu.pl).

${ }^{1}$ I will mostly speak of 'Kurmanji' rather than 'Kurdish'. While the latter is a larger field, including Sorani and other dialects as a separate standards, as well as, for some speakers, also Zazaki/Dimli/Kirmançki, the present study is limited to the Kurmanji variety of Kurdish, unable to do more. On the other hand 'Kurmanji Kurdish' might have been an alternative, however, 'Kurmanji' was chosen for the sake of brevity.
} 
For Turkish the placement of NPs and similar elements in postpredicative positions has been functionally related to discourse planning and information structure, roughly speaking, the (anti-)topic-focus system (Bainbridge 1972, Erguvanl1 1984, Schroeder 1995, Erdal 1999). For Kurmanji, however, it has been related to argument structure (Haig 2014, Haig \& Thiele 2014, Herkenrath 2018a), and for German, to issues of finiteness and illocution (Meisel 2011, Dryer 2013a, Dryer \& Gensler 2013). In syntactic terms, these categories can be related to the CP, VP, and IP systems (Rizzi 1997, 2004, Cinque 1999) respectively, roughly speaking. The surface phenomenon of postpredicativity thus assumes an epiphenomenal character, while the trilingualism of the community motivates the search for a unified account.

Since the allocation of functional areas to the three languages is not as straightforward as might seem, the present study aims (1) to set up a functional inventory of postpredicate construction types in the three languages, (2) to relate the three systems with each other, in order to better understand the trilingual 'repertoire' (Matras 2009) that is individually given in the field situation, (3) to identify issues that present obstacles to a straightforward categorisation, and (4) to qualitatively look at some of the latter in narrative-interactional context. These are descriptive and categorial goals for an explorative study.

This being a data-driven undertaking, Section 2 begins by presenting the data together with their documentation formats and categorisations. Section 3 takes a look at issues that have been under discussion in terms of postpredicativity in Turkish and Kurdish linguistics, including a brief typological look at German, with illustrations from the data. Sections 4 to 6 look at argument types, verb fronting, and discourse activation, respectively, with a focus on categorial overlaps and double motivations.

2. Data and methods. This study assembles Turkish, Kurmanji Kurdish and German data from three spoken-language corpora under construction: LiLaC, RUBA and SÎNEM (Herkenrath in preparation $a, b, c)$ into one trilingual supercorpus, for the purposes of the present study. The data were not collected with the aim to study any given grammatical topic but rather as thematically somewhat focused free-flowing conversations. LiLaC and RUBA were collected as part of an interdisciplinary project on the subjective experience of bureaucracy, in the German Ruhr Region in 2009, in German and Turkish respectively, ${ }^{2}$ while the topics of the ongoing SÎNEM collection have more of a cultural focus; all three contain language-biographical passages. The overview table in the appendix lists the concordanced corpus passages collected in the three languages with numbers of findings as well as providing information on conversational topics and speakers' multilingual repertoires.

Speakers display a variety of monolingual, bilingual, trilingual and multilingual repertoires, including, in most cases, immigration to Germany at different ages; meta data were collected as part of the conversations. The table in the appendix lists individual speakers' linguistic repertoires; languages spoken during recordings are boldfaced. Where it is known that a language was acquired at a later age, this approximate age is given in parentheses directly after the language in question, e.g., ' $>20$ ' means that exposure started in past-school-age young adulthood, at an age roughly over twenty. An information written as 'Celal, Kurmanji-Turkish ( $>6)$-German $(>20)$ ' means that according to what the participant said in the conversation, he acquired Kurmanji Kurdish from birth, Turkish after entering primary school at around six, and German when he came to Germany as a young man.

\footnotetext{
2 The LiLaC corpus (see first footnote: *) overall consists of 74 recordings; I exclusively work with those 29 recordings that I collected myself (LiLaC_AH). The RUBA data collection ('Ruhr Havzası'ndan Türkçe Bürokrasi Anlatıları/ Türkische Bürokratieerzählungen aus dem Ruhrgebiet/ Turkish Tales of Bureaucracy from the Ruhr Region') partly drew on field-methodological input from the LiLaC project, but was otherwise conducted on its own terms, in Turkish. The SÎNEM collection ('Sohbetên li ser zimên/ Conversations about language') is an ongoing pilot study with a data management plan under construction.
} 
As can be gathered from the table, most speakers (Ahmet, Haydar, İbrahim, Aygen, Celal, Fikret, Gülümser, Yeter, Veli, Meded, Mahir, Sezgin) immigrated to Germany as young adults, some as slightly older adults with work experience in Turkey and/or with children (Haluk, Şengül, Arif, Fahri, Şükran, Serko). Zanyar and Veysi were born in Germany, Taliha and Kerim arrived as primary-school-age children, Fidan as a teenager.

Most participants were between 35 and 55 of age at the time of recording. Fahri and Şükran were in their mid-to-late-twenties. Ahmet, Haydar and İbrahim were at retirement age. Most participants had spent decades in Germany, with the exception of Celal and Fikret, who had arrived a couple of years before the recording, and Fahri and Şükran, who had just barely arrived. Recorded in 2009, the LiLaC and RUBA data are now (in 2021) twelve years old. The SÎNEM data are fairly recent with the exception of Serko's recording, which was undertaken as a pilot attempt to conduct a Kurdish conversation in 2013, eight years ago.

Regarding the issue of any heritage status of their languages, among those who spent their childhood in Germany, Zanyar is a productive writer and speaker in Kurmanji Kurdish at the time of the recording; his Turkish is not mentioned during the conversation. Veysi is an active informal polyglott. Taliha is a community interpreter and child bilingualism activist; she developed her Turkish literacy mainly in adulthood. Kerim lost active use of Kurmanji Kurdish, his only first language, when his parents switched to Turkish as the family language after the 1980 military coup (during his primary school years) and has been involved in various attempts to recover it; on the other hand, he spent his school and university years well immersed in Turkish-speaking circles. Fidan is active in all her languages, but keeps a strict separation according to conversation partners. The Turkish speakers all actively use Turkish in their daily lives. The same applies for the Kurdish speakers: they, too, actively use Turkish in their daily lives, whereas Kurdish is restricted to special occasions - which they actively create. Nobody experienced Kurdish as a language of schooling, but most are involved in cultural or linguistic work. Veli is a productive writer, using Turkish. Meded is a speaker of Zazaki and has been involved in interpreting among other activities, using Turkish, Kurmanji, Zazaki, and German. Apart from the new arrivals, Arif is the only participant who claims not to speak any German at all; one may need to take this with a grain of salt.

Data elicitation was not systematically controlled for language choice; rather, the givens in the field were taken as they came, with the perspective of rounding up the collection in the longer run. Overall, the three languages are distributed over the recordings as specified in Table 1, e.g., 17 recordings of the 29 LiLaC_AH recordings were recorded in German, while 12 were mixed (mainly with Turkish, one with Kurmanji Kurdish). Of the 19 RUBA recordings, 17 were recorded entirely in Turkish, whereas two were mixed (one with Kurmanji, the other with German). Among the 55 SÎNEM recordings, 43 were recorded entirely in Kurmanji Kurdish, nine were mixed (usually Kurmanji with German, one German with Turkish), three were recorded entirely in German.

Taken together, the data cover two segments of what I consider a more or less connected community of Turkish-(Kurdish-)German speakers in Germany. While the LiLaC and RUBA data were collected in the loosely connected network of the large Ruhr area, slightly more than a decade ago, the SÎNEM data, more recent, are from Hessen, from a smaller place such that speakers know each other. The table in the appendix has been conceived as a means to locate speakers in individual examples within this larger collection. I do think that the specific structure of the combined corpus is real-life enough to raise some relevant questions, to be pursued in the future. This paper is an exploration into categorisation first and foremost. With the pandemic situation hopefully subsiding, the collection aims to complete at least some of the SÎNEM data to represent the full repertoire of individual speakers; this would require meetings in a variety of natural situations. As corpus building proceeds, I hope to be able to extract and present more detailed information. 
Thus, while the language separation between the three corpora is not strict, taken together, they form a trilingual collection of free-flowing language-biographical and expert conversations, as idiosyncratic windows into the linguistic repertoire of an internally diverse community.

\begin{tabular}{c|c|c|c|c|c} 
& German & Turkish & Kurmanji & mixed & $\Sigma$ \\
\hline LiLaC AH & 17 & 0 & 0 & 12 & 29 \\
\hline RUBA & 0 & 17 & 0 & 2 & 19 \\
\hline SÎNEM (pilot) & 3 & 0 & 43 & 9 & 55 \\
\hline$\Sigma$ & 20 & 17 & 43 & 13 & 103
\end{tabular}

Table 1: Trilingualism of the recordings (as of May 18, 2021)

Transcription, as a longterm process, is still ongoing for all three corpora, with the SÎNEM pilot corpus being the most recent and least advanced one in this respect. Passages have so far been selected for transcription on the basis of an interest in language-biographical or other issues (Herkenrath 2017, 2018b, 2020), thus not with any specific interest in the phenomena presently under investigation. Table 2 presents information on the length of the recordings and state of ongoing transcriptions:

\begin{tabular}{|c|c|c|c|c|c|c|c|c|c|c|}
\hline \multirow[t]{2}{*}{ Corpora } & \multicolumn{7}{|c|}{ Recordings } & \multicolumn{3}{|c|}{ Transcriptions } \\
\hline & period & place & languages & number & hrs & $\min$ & $\min \emptyset$ & hrs & $\min$ & $\%$ \\
\hline LiLaC_AH & 2009 & Ruhrgebiet & $\begin{array}{l}\text { German, } \\
\text { Turkish } \\
\text { (Kurmanji) }\end{array}$ & 29 & 31.3 & 1,880 & 64 & 5.2 & 316 & 16.8 \\
\hline RUBA & 2009 & Ruhrgebiet & $\begin{array}{l}\text { Turkish } \\
\text { (Kurmanji) }\end{array}$ & 19 & 25.8 & 1,548 & 81 & 8.0 & 480 & 31.0 \\
\hline $\begin{array}{l}\text { SîNEM } \\
\text { (pilot) }\end{array}$ & $\begin{array}{l}2013, \\
2017-\end{array}$ & Hessen & $\begin{array}{l}\text { Kurmanji, } \\
\text { Turkish, } \\
\text { German } \\
\text { (Zazaki) }\end{array}$ & 55 & 113.0 & 6,817 & 123 & 3.3 & 201 & 3.3 \\
\hline & & & 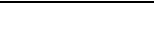 & 103 & 170.7 & 10,245 & 99.4 & 16.5 & 997 & 9.7 \\
\hline
\end{tabular}

Table 2: Corpora, Length of recordings and state of transcriptions (as of May 18, 2021)

From a methodological point of view, the described data situation offers both potential and challenges for the present research. The obvious advantage is the free-flowing character and communicative authenticity of the grammar-function relations that can be observed in them. The challenge is that due to the structure of the corpus and the typological constellation, comparability has to be established as part of the analysis.

The approach taken towards categorisation of post-predicative elements was a manual concordancing based on a linear reading of passages of transcripts, aiming at inclusion of roughly a handful of speakers for each language, and a collection of a roughly equal number of findings for each language. All elements or constituents positioned after a predicate were counted as findings. All in all, 161 minutes of transcribed Turkish passages were considered, containing 407 postpredicative findings, 129 minutes of Kurmanji, containing 403 postpredicative findings, and 45 minutes of German, containing 401 postpredicative findings: 1,211 findings all in all.

3. Different functional motivations of postpredicativity in the three languages. The placement of linguistic elements in postpredicative positions has been functionally related to discourse planning and information structure in Turkish, argument structure in Kurmanji, and verb inflection in German. This section reviews some issues under discussion in Turkish and Kurdish linguistics, including a brief typological look at German. 
3.1. KURMANJI KURDISH: GOAL ARGUMENTS (VP LEVEL). In agreement with cross-linguistic observations (Malchukov, Haspelmath \& Comrie 2010: 9), Haig (2014) and Haig \& Thiele (2014) show how the post-predicative position in Kurmanji hosts so-called 'goals', a broad category in their approach that includes locational goals of verbs of motion, recipients of verbs of transfer, 'endpoints of events' in an iconic sense, as well as addressees of verbs of speech. This situation applies to bare nouns, but also semantically transparent noun-derived adpositions (e.g. cem 'near', nav 'between', ser 'on'). NPs governed by non-lexical adpositions are found in pre-predicative position. Herkenrath's (2018a) literary data by and large confirm these observations. Gündoğdu (2019: 108) discusses the typologically unusual pattern in light of contact with VO languages at the proto stage and dialectal variation.

Example (2) illustrates this state of affairs; it contains a $w h$-element and a number of oblique NPs, all functioning as goals and placed in post-predicative position:

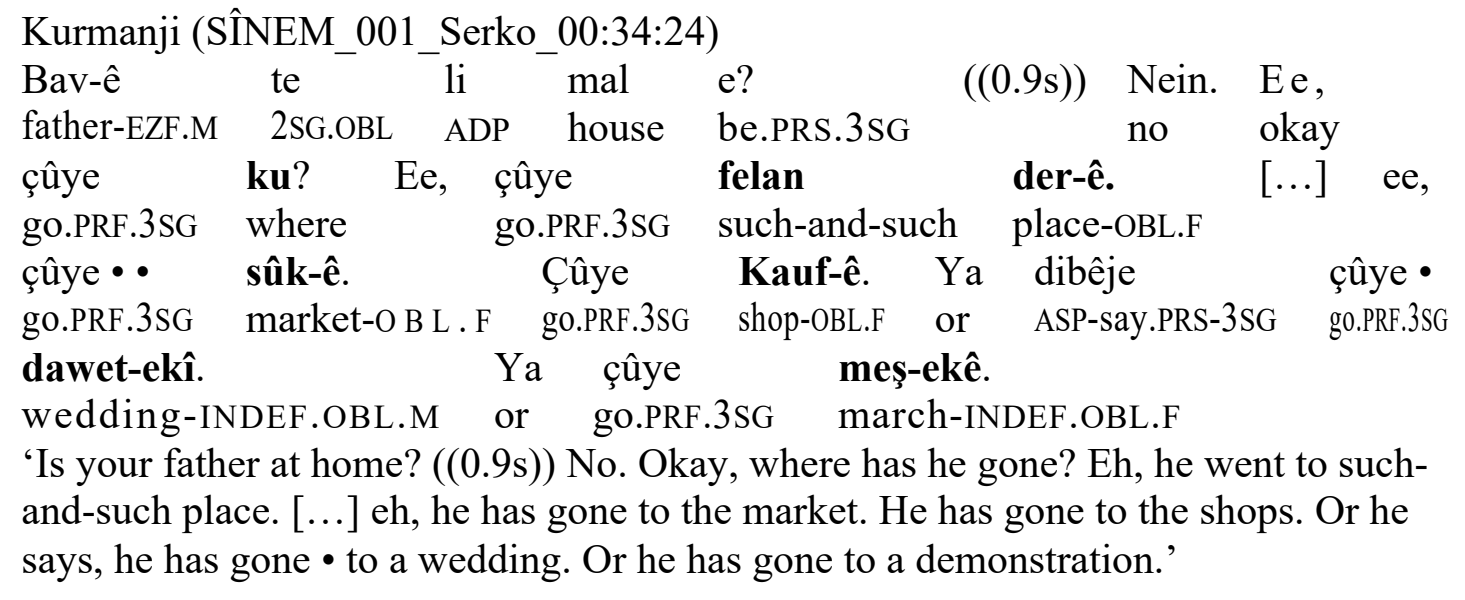

3.2. GERMAN: VERB POSITION (IP LEVEL). German, considered from a typological perspective, is one of only 67 languages worldwide that have two 'dominant orders' of subject, direct object and verb (Dryer \& Haspelmath 2013, Dryer 2013a); in this connection Turkish is mentioned as OV, so are Zazaki and Central Kurdish, Kurmanji is not mentioned (Dryer $2013 b$ ). With respect to oblique complements, Turkish is XOV, Kurdish is not mentioned, German has 'no dominant order' (Dryer \& Gensler 2013).

From a multilingual perspective, German has been characterised as underlyingly SOV. Certain syntactic contexts require verb movement for checking of functional categories related to finiteness; objects (and other elements) may then end up in post-verbal position, making for an SVO effect in non-subordinated clauses at the syntactic surface (Meisel 2011: 6f). Erdal (1999), comparing German with Turkish, pays more attention to the actual postfield, which fulfills a specific discourse function. Postverbal elements may appear both in the the postfield and in the middle field, the distinction often requiring subtle interpretation of syntax and of discourse context.

Example (3), in German, illustrates a succession of post-predicative elements appearing at the syntactic surface: a subject (the impersonal pronoun man), two adverbial phrases: $z u$ neunzig Prozent 'at ninety percent' and zu damaliger Zeit 'at that time', a direct complement: Kurdisch 'Kurdish', and its specification, delivered as an afterthought: Kurmanjî. The finite verb spricht '[one] speaks' is in second position, which is where finite verbs surface in nonsubordinate constructions. Excepting the afterthought element Kurmanjî, the postpredicative elements are all situated in the so-called middle field. Postpredicativity in this example is an effect of the verb-second phenomenon; it has no particular discourse function nor any relationship to the specific argument structure of the verb. 
(3) German (SÎNEM_004_Kerim_00:04:27).

$\begin{array}{llllllll}\text { In meinem } & \text { Dorf, } & \text { wo } & \text { ich, } & \text { hm, auf } & \text { die } & \text { Welt } \\ \text { ADP } & \text { 1SG.PSS-N.DAT } & \text { village } & \text { where } & \text { 1SG.NOM } & \text { ADP } & \text { DET.F.ACC } & \text { world } \\ \text { gekomm bin, } & \text { äähm, } & \text { spricht } & \text { [man] } & ((1.2 \mathrm{~s})) & \text { [zu } & \\ \text { come.PAR be.PRS.1SG } & & \text { speak.PRS-3SG } & \text { one } & \text { ADP } & \end{array}$

$\begin{array}{lllll}\begin{array}{l}\text { neunzig } \\ \text { ninety }\end{array} & \begin{array}{l}\text { Prozent }], \\ \text { percent }\end{array} & \text { ähm, } & \begin{array}{l}\text { [zu } \\ \text { damaliger }\end{array} & \begin{array}{l}\text { Zeit } \\ \text { ADP }\end{array} \text { ä.that.time-ADJ-F.DAT } \\ \text { time }\end{array}$

[Kurdisch]. ((0.5s)) [Kurmanjî].

Kurdish Kurmanji

'In my village, where I, ehm, was born, ehm, • people speak ((1.2s)) at ninety percent, ehm, at that time, ehm, $\bullet$ Kurdish. $((0.5 \mathrm{~s}))$ Kurmanji.'

3.3. TURKISH: ILLOCUTIONAL VERB CATEGORIES (IP) AND DISCOURSE FLOW (CP LEVEL). The discussion of phenomena of postpredicativity in Turkish goes back at least to Mundy (1955) (Lewis 1967: 241, Bainbridge 1972: 16-21, Erdal 1999); it has since then been discussed not just in grammatical terms, but also in terms of style and register, also outside of linguistics (Lewis 1967, Erdal 1999). Functionally, the literature has distinguished two phenomena: the placement of pre-mentioned information after a predicate in its basic final position, a discourse phenomenon, and the fronting of predicates for illocutional reasons, leading to other effects of postpredicativity, an IP-related phenomenon (Lewis 1967, Erdal 1999 etc.). Bainbridge (1972: 23) analyses 'inverted' constructions as the syntactic effects of utterance planning in interaction, a discourse phenomenon. Erguvanl1-Taylan (1984: 50-59) mentions categories such as backgrounding, afterthought, de-focusing, 'discourse-predictability' and given information, next to the possibility of elements ending up after a fronted verb.

Schroeder (1995) analyses how different aspects of so-called 'topical strings' can be active in a discourse context in unplanned spoken data, paying particular attention to the role of postpredicative (first-person and other) pronouns. Erdal (1999) distinguishes postverbal elements in the middle field, i.e. after a fronted interrogative, imperative or emotionaly marked verb, from those in the postfield, i.e. after a non-fronted verb. Extraposition to the postfield may apply to 'pre-referenced' elements or information related to them, allowing a gradation of information status with effects of 'anti-rhematicity', defocusing, non-emphatic status, or backgrounding. Doğruöz \& Backus (2007) differentiate the restriction to nonfocused elements in post-predicative position not just for Dutch Turkish but also for monolingual Turkish. From the entirety of this discussion, it emerges that determining the information status of postposed elements involves some rather intricate differentiations of discourse categories; see also Chafe (1994: 135ff etc.) for a discussion of the aggregative state of topics and the gradational status of their activation.

Example (4), a scenically restaged incident of a police control, may serve to illustrate both phenomena. In terms of discourse knowledge, in this little scence, a friend of the speaker's (arkadaş) and a German policeman (polis) are the relevant human actants; both are mentioned in the first sentence, where they occupy canonical subject and object positions, respectively. When briefly rementioned in passing, this time both in subject roles, they are postposed to the respective predicates: gidiyor arkadass 'he is driving the friend' and anlyyor • $o$ polis 'he understands $\bullet$ that policeman'. Likewise postposed are the adverbial elements arabayla 'with the car', yaninda 'with him/in his pocket' and hemen 'at immediately'; while not explicitly pre-mentioned, they can be interpreted as expectable and therefore semiactivated knowledge components of the scence.

In terms of verb illocution, the emphatic (and repeated) imperative form in 'get out' can be interpreted as fronted for illocutional reasons, making the NP arabadan 'from the car' appear in postpredicative position. One might add that the car $(a r a b a)$ is a pre-mentioned entity in this passage at the same time, next to being a dominant physical presence in the 
narrated scene. Its post-predicative positioning can therefore be analysed as (at least) doubly motivated. It is this kind of double motivation that will pose systematic challenges to the analysis, to be reconsidered in subsequent sections.

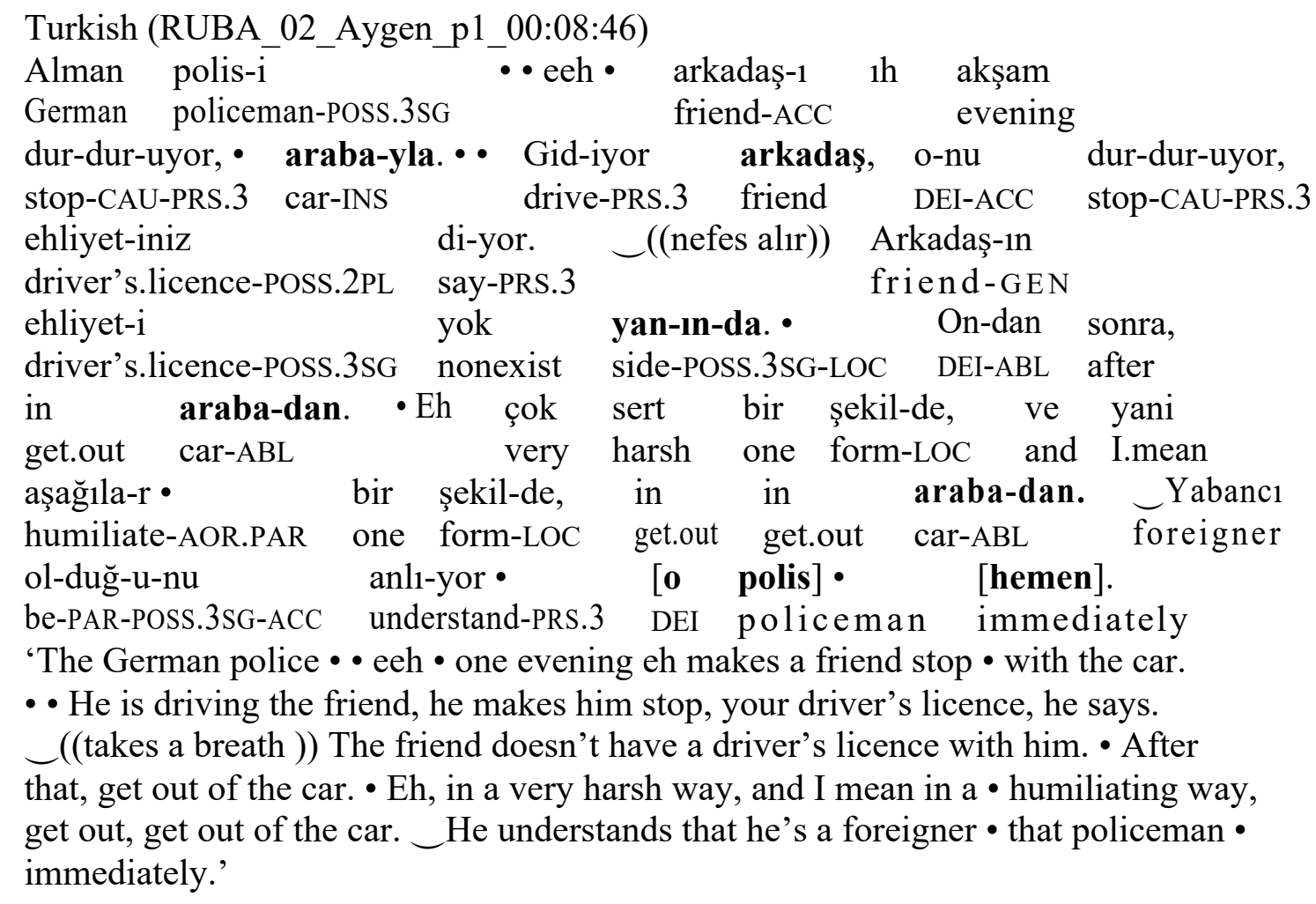

To sum up, we can expect to find post-predicative elements in all three languages, albeit differently motivated: (i) in terms of argument type in Kurmanji, (ii) in terms of verb fronting and illocution in German and Turkish, (iii) in terms of topic activation status in Turkish and German. Section 3 raised some possibilities with respect to phenomena of double motivation. In addition to this, overlaps between the three languages need to be explored: To what extent can argument type play a role beyond Kurmanji? To what extent can verb movement play a role beyond German and Turkish? How about the role of discourse flow beyond Turkish and German?

Since the assessment of activation status for a given referent and the interpretation of verb position will require not just local semantic and syntactic analysis, but also interpretation of the wider discourse context and narrative plot, the analysis addresses the three levels stepwise in a bottom-up way: beginning with argument types, moving from there to verb position and, finally, interpretation of discourse activation status. Examples will qualify for consideration at the higher level after exclusion of the lower-level criteria, however, overlaps and double motivations will be specifically addressed.

4. Argument types: Goals and beyond. This section takes a look at the distribution of argument and non-argument types across the three languages. 'Argument type' will be considered to have three dimensions: first, the semantic argument type and syntactic role, e.g., goal, direct object, but also subject; second, syntactic size, e.g., clausal, nominal, pronominal etc.; third, a specific matrix type. These three sides of argument categorisation will be considered separately.

4.1. SEMANTIC ARGUMENT TYPE. According to the literature discussed in 3.1, the semantic argument type is relevant first and foremost for Kurmanji, where goals of verbs of motion 
(122 findings in the data), recipients of verbs of transfer (10), addressees of speech (1) and endpoints of events (16) can be expected to play a role, next to necessitative (3) and passive constructions (25). This situation is partially reflected in Table 3: in the Kurmanji data, goals of various types account for more than $44 \%$ of all post-predicative elements, 179 in absolute figures.

By contrast, in Turkish and German, where adverbials, particles and other non-arguments figure more prominently, the proportion of goals among post-predicative elements is considerably lower. It is also lower when only goals, direct objects and subjects are considered, i.e., the main players in the valency structure of predicates. Within this area, Turkish shows a roughly equal distribution, with subjects forming the largest group. In German, direct objects are the largest group, while goals seem to be of lesser relevance. In Kurmanji, next to goals, direct objects also form a large group, while subjects are few. These results leave us with a need to account for still over half of the post-predicative elements in Kurmanji that are nongoals, in particular the $33.7 \%$ that are direct objects.

\begin{tabular}{|c|c|c|c|c|c|c|c|c|}
\hline & $\begin{array}{l}\text { Turkish } \\
\text { absolute }\end{array}$ & $\%$ & $\begin{array}{c}\text { Kurmanji } \\
\text { absolute }\end{array}$ & $\%$ & $\begin{array}{c}\text { German } \\
\text { absolute }\end{array}$ & $\%$ & $\begin{array}{l}\sum_{\text {absolute }} \\
\end{array}$ & $\%$ \\
\hline adverbial & 134 & 32.9 & 36 & 8.9 & 125 & 31.1 & 295 & 24.3 \\
\hline direct object & 46 & 11.3 & 132 & 33.7 & 85 & 21.1 & 263 & 21.7 \\
\hline goal & 55 & 13.5 & 179 & 44.4 & 16 & 3.9 & 250 & 20.6 \\
\hline subject & 67 & 16.4 & 23 & 5.7 & 48 & 11.9 & 138 & 11.3 \\
\hline particle & 80 & 19.6 & 20 & 4.9 & 29 & 7.2 & 129 & 10.6 \\
\hline predicate noun & 0 & 0 & 2 & 0.4 & 64 & 15.9 & 66 & 5.4 \\
\hline negator & 0 & 0 & 0 & 0 & 23 & 5.7 & 23 & 1.8 \\
\hline attribute & 7 & 1.7 & 3 & 0.7 & 10 & 2.4 & 20 & 1.6 \\
\hline numeral $^{3}$ & 12 & 2.9 & 7 & 1.7 & 1 & 0.2 & 20 & 1.6 \\
\hline verb in V-V construction & 6 & 1.4 & 1 & 0.2 & 0 & 0 & 7 & 0.5 \\
\hline$\sum$ & 407 & 100 & 403 & 100 & 401 & 100 & 1,211 & 100 \\
\hline
\end{tabular}

Table 3: Post-predicative argument and non-argument types in terms of syntactic role

4.2. SYNTACTIC SIZE. By 'syntactic size', I refer to the syntactic weight and complexity of an element, i.e., its status as a clause, verb phrase, nominal or adpositional phrase, or pronoun respectively deictic. This categorisation is tentative and pre-terminological at the present stage. The basic impression at the moment is that some syntactic category is involved that goes beyond argument-structural concepts and syntactic roles and that involves issues such as (sometimes just potential) internal complexity. ${ }^{4}$ Post-predicative direct objects in Kurmanji, whose frequency requires explanation, do have the largest proportion of clauses $(45 \%)$ and also of verb phrases (24\%) among the three languages, whereas in Turkish and German, postpredicative direct objects largely tend to be NPs; see Table $4:^{5}$

\footnotetext{
${ }^{3}$ In Turkish, the category 'numeral' seems to be an element that tends to occur postpredicatively. There are twelve such findings in the data, suggesting some interplay of various factors; for reasons of space, they cannot be dealt with here.

${ }^{4}$ One reviewer suggests that use of this term might suggest that a systematic hierarchy is already assumed at this stage (rather than a tendency under preliminary consideration). However, this paper is in search of categorisations, starting from the findings in the corpus.

5 The Kurmanji data do also contain NPs in this position in 35 findings, among them 24 (roughly two thirds) with gotin 'say' in the meaning of 'call, name', the remaining ones with verbs such as (çê)kirin 'make' (2x), êvîsandin 'learn', guherandin 'change', kirin 'do', piroz kirin 'celebrate', qedandin 'finish', xistin 'throw', and xwendin 'read, study, recite' (3x). Among these findings, some might have to be reconsidered under aspects of utterance planning at some point; some are from a speaker with Zazakî as his first language.
} 


\begin{tabular}{l||r|r|r|r|r|r|r|r} 
& \multicolumn{2}{l|}{$\begin{array}{l}\text { Turkish } \\
\text { absolute }\end{array}$} & $\begin{array}{l}\text { Kurmanji } \\
\text { absolute }\end{array}$ & $\begin{array}{l}\text { German } \\
\text { absolute }\end{array}$ & $\begin{array}{l}\text { \% } \\
\text { absolute }\end{array}$ & $\%$ \\
\hline \hline clause & 13 & 28.2 & 60 & $\mathbf{4 5 . 4}$ & 33 & 38.8 & 106 & 40.3 \\
\hline VP & 1 & 2.1 & 32 & $\mathbf{2 4 . 2}$ & 6 & 7.0 & 39 & 14.8 \\
\hline NP/AdpP & 22 & $\mathbf{4 7 . 8}$ & 35 & 26.5 & 38 & $\mathbf{4 4 . 7}$ & 95 & 36.1 \\
\hline pronoun/deixis & 10 & 21.7 & 5 & 3.7 & 8 & 9.4 & 23 & 8.7 \\
\hline \hline$\sum$ & 46 & 100 & 132 & 100 & 85 & 100 & 263 & 100
\end{tabular}

Table 4: Size of postpredicative direct objects

Complement clauses in Kurmanji are finite and introduced by conjunctions; they follow the matrix verb that governs them. Subjunctive verb phrases governed by modal verbs ('can', 'must', 'want' etc.) also follow these. Given this head-initial structure of the two construction types, both phenomena taken together explain to a large part the frequency of direct objects in postpredicative position; the remainder (some 26\% NPs/AdpPs and some 3\% pronouns or deictics) will be reconsidered in Section 6. In (5), the subjunctive VP beginning with bêjî 'that you say' is positioned after the governing modal predicate dixwazi 'you want', and the clausal (interrogative) complement zimanê kurdî çi rewşê de, peşketina wî̀ ç̧awa ye 'in what state is the Kurdish language $\cdot$ how is its progress' is positioned after the governing matrix, the verbum dicendi bêjî 'that you say'.

(5) Kurmanji (SÎNEM_001_Serko_00:00:47)

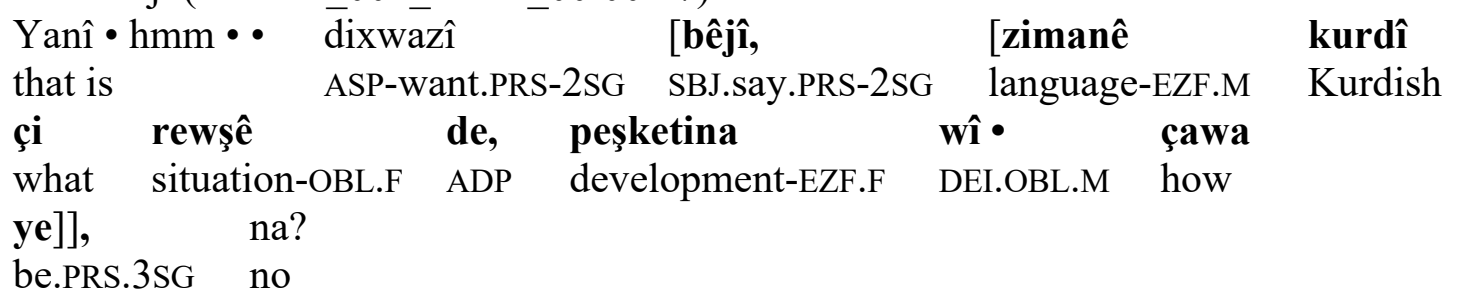

'That is • eh $・$ you want to say, in what state is the Kurdish language $\bullet$ how is its progress, right?'

In German, the situation with respect to complement clauses looks similar. Example (6) can be interpreted as a subordinate clause rather on the VP side, i.e., sharing the subject and tense anchoring with the matrix; it appears in postpredicative position:

(6) German (SÎNEM_004_Kerim_00:12:57)

Man hat halt versucht, sich sooo, ääh, ((1.1s))
one have.PRS.3SG PTC try.PAR RFL as
unauffällig wie möglich zu verhalt-en.
inconspicuous as possible to behave-VN
'You just tried to, eeeh, $((1.1 \mathrm{~s}))$ behave as inconspicuously as possible.'

In Turkish, head direction in subordination is opposite, such that subordinate clauses tend to precede the matrix. Still, in Turkish, too, $29 \%$ of all post-predicative direct objects are clauses. - By contrast, the occurrence of post-predicative subjects in Kurmanji cannot be explained in terms of syntactic size, as over $60 \%$ of them are NPs; see Table 5. In Turkish and German, which additionally have pronominal and deictic subjects, the proportion of small-size elements among postpredicative subjects is even higher: over $96 \%$ in the Turkish and over $95 \%$ in the German data, where they may cliticise to a fronted verb, as in example (7). However, while these high frequencies can be expected in terms of verb fronting or 
discourse activation status in these two languages, the $60 \%$ in Kurmanji are less expectable; they will be reconsidered in Section 6 .

\begin{tabular}{|c|c|c|c|c|c|c|c|c|}
\hline & $\begin{array}{l}\text { Turkish } \\
\text { absolute }\end{array}$ & $\%$ & $\begin{array}{l}\text { Kurmanji } \\
\text { absolute }\end{array}$ & $\%$ & $\begin{array}{l}\text { German } \\
\text { absolute }\end{array}$ & $\%$ & $\sum_{\text {absolute }}$ & $\%$ \\
\hline clause & 2 & 2.9 & 9 & 39.1 & 1 & 2.0 & 12 & 8.6 \\
\hline VP & 0 & 0 & 0 & 0 & 1 & 2.0 & 1 & 0.7 \\
\hline NP/AdpP & 30 & 44.7 & 14 & 60.8 & 8 & 16.6 & 52 & 37.6 \\
\hline pronoun/deixis & 35 & 52.2 & 0 & 0 & 38 & 79.1 & 73 & 52.8 \\
\hline$\sum$ & 67 & 100 & 23 & 100 & 48 & 100 & 138 & 100 \\
\hline
\end{tabular}

Table 5: Size of postpredicative subjects

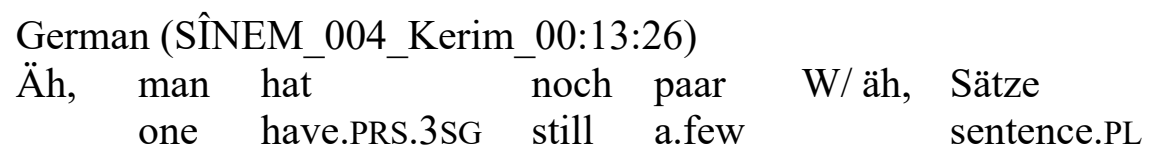

mit-einander ausgetauscht, aber das war's.

with-each.other exchange.PAR but DEI be.PST.3SG=3SG.N.NOM

'Eh, you continued exchanging a few w/ eh sentences with each other, but that was it.'

4.3. PREDiCATE TYPE. Complement clauses in Turkish may also end up in post-predicative position just depending on the type of matrix predicate, particularly in connection with de'say', as observed in six findings, only half of them by speakers of Kurdish. (8) is from a speaker who grew up as a Turkish monolingual:

$$
\begin{aligned}
& \text { Turkish (RUBA_06_Yeter_00:11:13) } \\
& \text { Art1k de-di-m: İste-mi-yor-um. } \\
& \text { finally say-PST-1SG want-NEG-PRS-1SG } \\
& \text { 'I finally said: I don't want it.' }
\end{aligned}
$$

In Kurmanji, the verbum dicendi gotin 'say' seems to have an even stronger effect, there being 73 findings of post-predicative direct objects, among them 45 of clause-size, but also 24 NPsized ones, and four with pronominal or deictic elements; see (9) and (10):

$$
\begin{aligned}
& \text { Kurmanji (SÎNEM_008_Mahir_00:30:18) }
\end{aligned}
$$

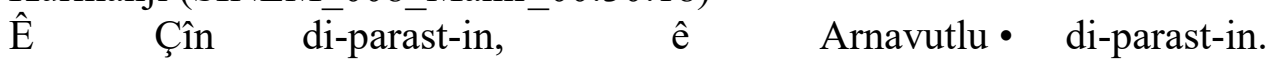

$$
\begin{aligned}
& \text { EZF.PL China ASP-support.PST-PL EZF.PL Albanian ASP-support.PST-PL } \\
& \text { Ee. - E Ewana • ee... Her daqqa erê maoîst, sosyalfaşîst. } \\
& \text { 3PL every minute yes Maoist social.fascist } \\
& \text { Mesela me ji wan re di-go maôst, } \\
& \text { for.instance 1PL ADP 3PL.OBL ADP ASP-say.PST.3SG Maoist } \\
& \text { (ma) jî ji me re di-go } \\
& \text { (3PL.PL) also ADP 1PL.OBL ADP ASP-say.PST.3SG social.fascist }
\end{aligned}
$$

'Those who supported China, those who - supported the Albanians. Yeah. • They

- eh... All the time, yes, Maoist, social fascist. For instance, we used to call them

Maoists, and they used to call us social fascists.'

(10) Kurmanji (SÎNEM_002_Veli_p1_00:06:08)

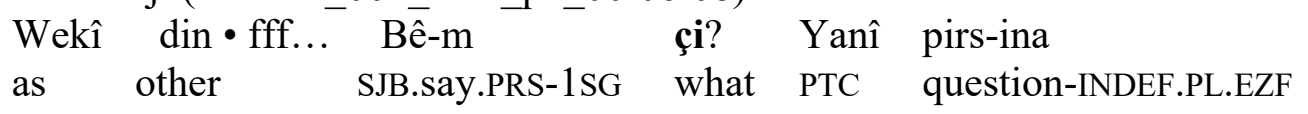




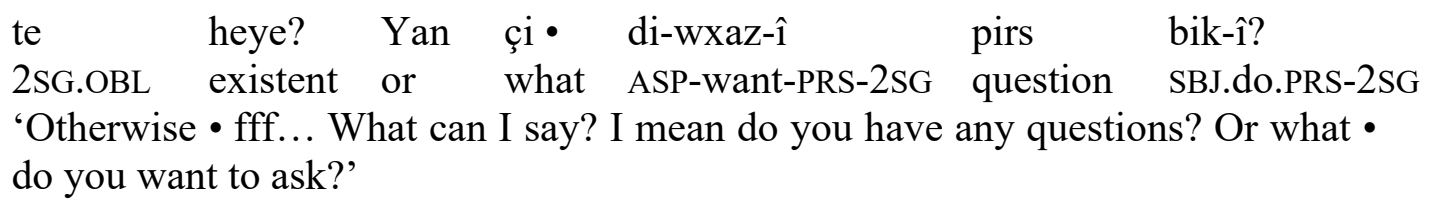

In German, all eight post-predicative direct objects following 'say' are clauses; there is no need to account for them other than in terms of syntactic size.

5. Verb fronting: Some overlaps. Verb fronting leading to various elements ending up in postpredicative position has been reported to be a matter of finiteness in German and of several types of illocutionary quality in Turkish; see the discussions in 3.2 and 3.3. Among the 401 German findings, there are $334(83 \%)$ in which the verb has been fronted to the second position (example 2 above). There is no reference to verb fronting in the literature on Kurmanji Kurdish, and the data do not seem to contain any examples. This section just looks at a few examples in which verb fronting is not straightforward or needs to be analysed as one of two possible motivations for postpredicativity, in Turkish.

5.1. EMOTIONALITY COMBINED WITH DISCOURSE ACTIVATION. We saw in example (4) in Section 3.3 how a postpredicative position can be doubly motivated, namely, where the predicate has some specific illocutional characteristic, in that case imperative, and the postposed element is a pre-mentioned entity at the same time. The episode in (11) is about the experience of not knowing how to buy the most basic food, shortly after new arrival in Germany, an experience of the first generation of labour migrants back in the nineteensixties. This clearly is an existentially emotional memory, an effect that is linguistically transported by the detailedness of the account and the intensifying discourse particle yahu. The matrix predicate sormad yahu 'they didn't ask, man' has a certain emotional dynamic and might therefore be argued to be in some fronted position, albeit not at the very beginning of the utterance. At the same time, the topic transported in the postpredicative finite question, regarding the knowledge of German, can be argued to have been implied throughout the passage. Taken together, this would make for a double motivation:

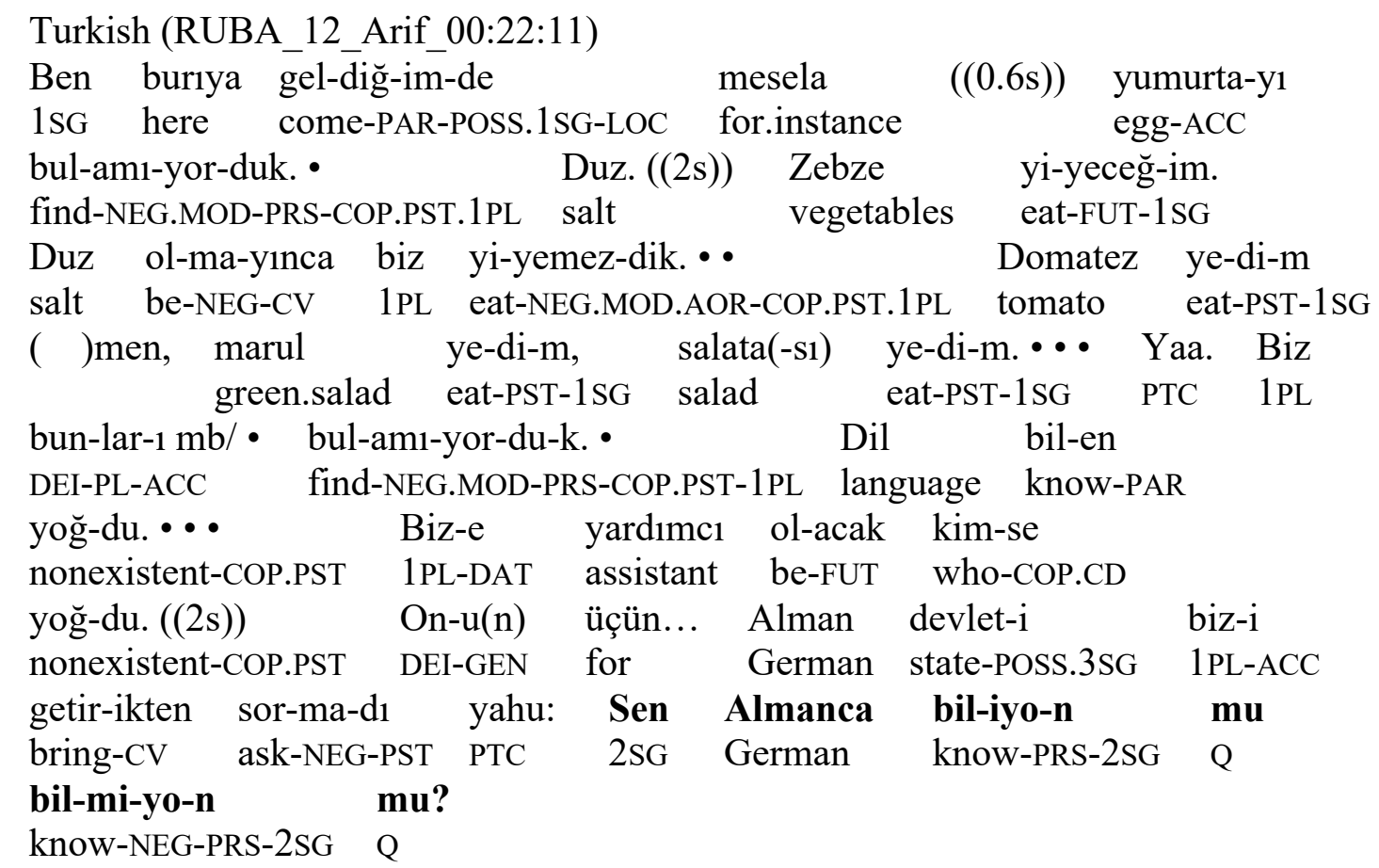


'When I came here, for instance $((0.6 \mathrm{~s})))$, we couldn't find eggs. • Salt. ((2s)) I'm going to eat vegetables. As there was no salt, we couldn't eat any. $\bullet$ I ate tomatoes, ( ), I ate green salad, I ate ( ) salad. $\bullet \bullet$ Oh well. We couldn't $\bullet$ find these. $\bullet$ There wasn't anybody who knew the language. $\cdots$. There wasn't anybody who might have helped us. Therefore... When the German state brought us here, it didn't ask, man: Do you or don't you know German?'

In (12), the predicate bilmiyorsun $k i$ 'you don't know' can be interpreted as emotionally dynamic and therefore fronted; it appears at the very beginning of the - short - utterance. At this point, the narrative is restaged in the present tense. Formally, the verb is impersonalised by means of second-person marking, which one can interpret as a strategy to mitigate its emotional impact, while the particle $k i$ adds a nuance of inevitable givenness. At the same time, however, one might argue that it is the complement clause neyin ne olduğunu 'what's what'), which refers to active information, that has been postposed for backgrounding effect. In this sense, again, the syntactic pattern can be analysed as being doubly motivated.

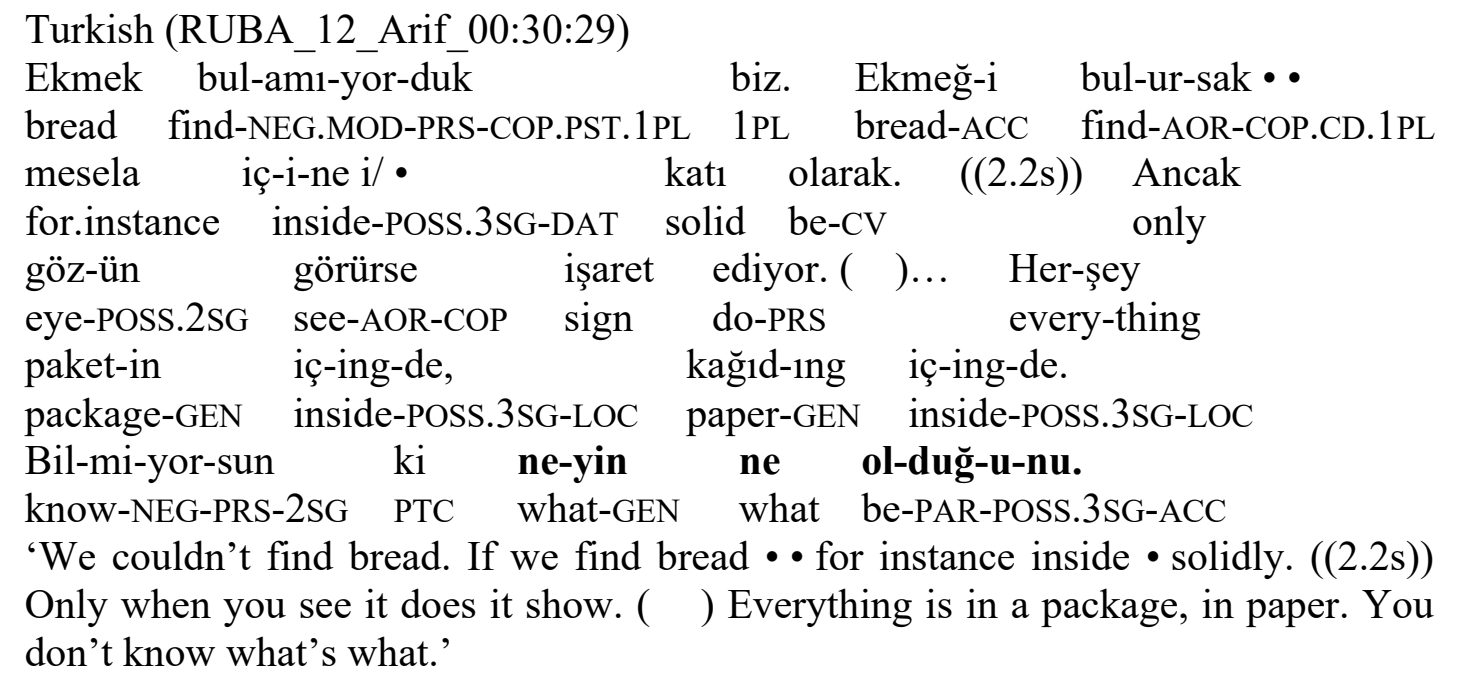

Together, these two examples evoke aspects of social reality in the background of the narrated events that can be thought of as an imagined or real discourse, thereby accounting for backgrounding effects. It is against this background that the emotional dynamics of speaking and even thinking are highlighted, such that a (partial or complete) syntactic fronting of one verbum dicendi (sormad c yahu 'it didn't ask, man') and one verbum sentiendi (bilmiyorsun ki 'you don't know, hey') might be motivated. Both motivations together can be grounded in the language-biographical content of the data.

5.2. DyNAMICS ON A SCALE OF (NON-)MOTION, AND DISCOURSE ACTIVATION. Predicates in Turkish have been reported to front also when expressing motional dynamics; see the discussion in 3.3. This category again may overlap with discourse activation. In (13), giderim 'I'd go' is a verb of motion, bakkala 'to the shop' is a goal. While in Turkish, 'goal' is not a relevant category for postpredicativity, motion can be. The utterance with the motion verb marks the transition between a generalising comment and its everyday-life exemplification, involving an increase in motional dynamics. Such an interpretation may justify an analysis of the predicate as having been fronted. At the same time, however, bakkal 'the shop' has some status of discourse activation in this passage of conversation in which the everyday economical situation of (pre-)retired mine workers is being discussed. Thus again, we see a potentially double motivation. 
(13) Turkish (RUBA_01_Ahmet_00:05:00_Haydar)

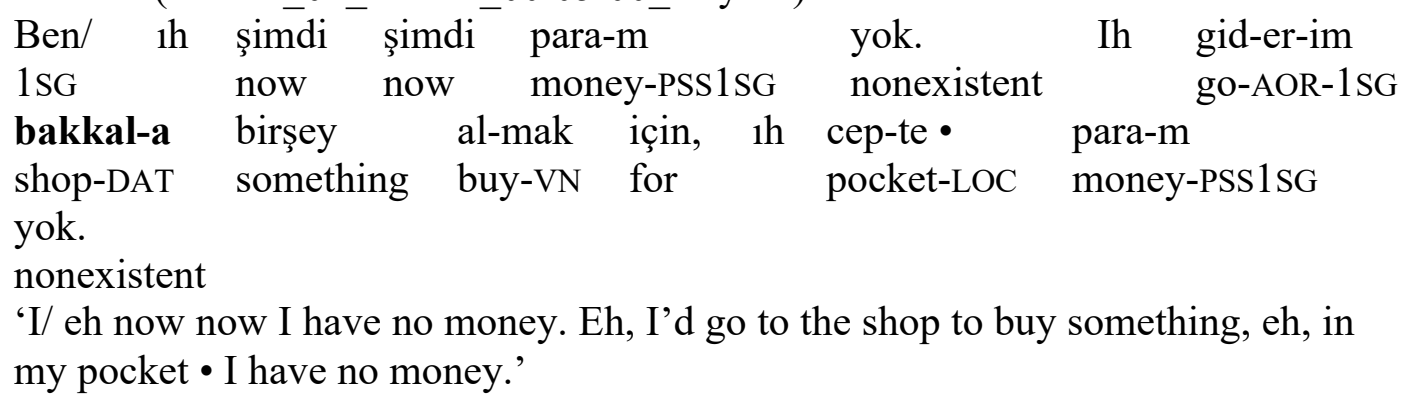

In (14), the conversation is about the situation for women on (commuter) trains, something that had kept the speaker's parents from sending her to higher education, some twenty years back in Turkey. The topic of trains can thus be regarded as an activated one, motivating backgrounding by syntactic means. At the same time, again, the utterance beginning with the motion verb geziyorlar 'they walk around' marks a transition between a generalising comment and its dynamic illustration. In contrast to (13), here, the verb of motion is not a telic one; it does not have a goal.

(14) Turkish (RUBA_06_Yeter_00:20:35)

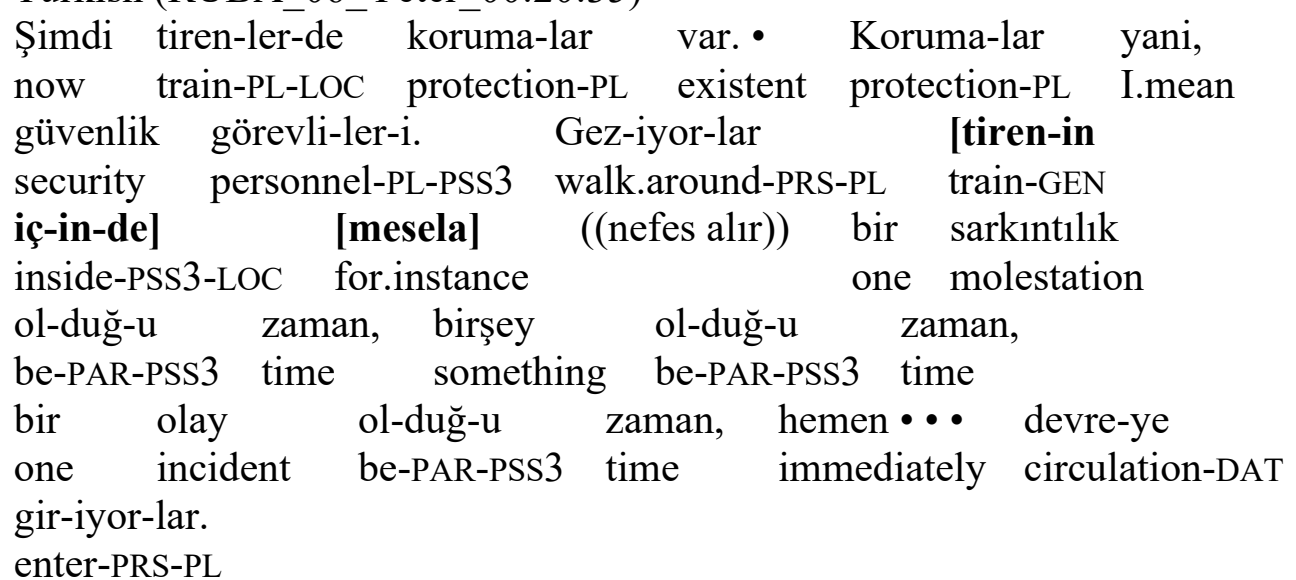

'Now there's protection on the trains. Protection, I mean, security personnel. They walk around inside the train for instance ((takes a breath)) when there's molestation, when there's something, when there's some incident $\cdots$ they immediately interfere.'

In (15), there is no movement involved but just dynamics of the action and/or situation. The speaker, who arrived in Germany more recently, evokes a socially and economically dynamic situation, before the economic crisis, related to him by first generation visitors to his café. Taken together, these three examples suggest a transition between goal-oriented movement, just movement, and just dynamic action that may or may not imply movement - on a semantic continuum that at one point reaches overlap with the category 'goal', relevant for Kurmanji, while involving additional semantic and also discourse-level categories.

\begin{tabular}{|c|c|c|c|c|c|}
\hline $\begin{array}{l}\text { Eski-den } \\
\text { old-ABL }\end{array}$ & $\begin{array}{l}\text { anlat-1yor-lar. } \\
\text { tell-PRS-PL }\end{array}$ & $\begin{array}{l}\text { Kahve-ye } \\
\text { café-DAT }\end{array}$ & $\begin{array}{l}\text { gir-diğ-i } \\
\text { enter-PAR-PSS3 }\end{array}$ & $\begin{array}{l}\text { zaman } \\
\text { time }\end{array}$ & $\begin{array}{l}\text { bir-i-si } \\
\text { one-PSS3-PSS3 }\end{array}$ \\
\hline 0 & $\begin{array}{l}\text { di-yor-muş } \\
\text { say-PRS-COP.EV }\end{array}$ & $\begin{array}{l}\text { ki • } \\
\text { PTC }\end{array}$ & $\begin{array}{l}\text { masa-lar-a } \\
\text { table-PL-DA }\end{array}$ & $\begin{array}{l}\text { bak. } \\
\text { look }\end{array}$ & $\begin{array}{l}\text { Kim } \\
\text { who }\end{array}$ \\
\hline
\end{tabular}




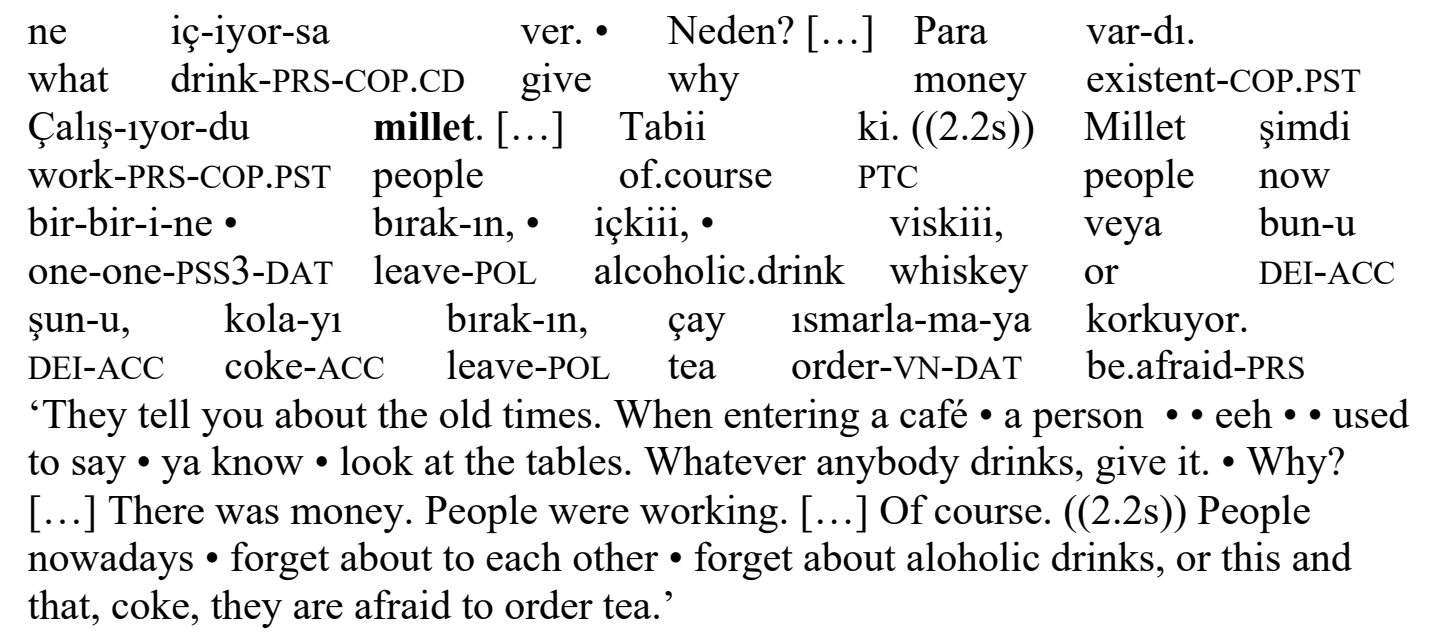

6. Discourse activation status. It has been seen that discourse activation status in Turkish may overlap with verb fronting. On the other hand, in Kurmanji, non-goals can be postpredicative as long as they are large enough. In German, transitions between the middle field and the postfield can often appear to be fuzzy. There remains an area of discourse activation status to explore, namely where it is just discourse activation that accounts for the postpredicative position of an element. This section looks at afterthought qualifications and at in-passing reactivation of referents active in discourse knowledge.

6.1. AFTERTHOUGHT QUALIFICATIONS. Afterthought qualifications occur in all three languages. In (16), in Turkish, a temporal detail that one might have taken for granted is nevertheless added:

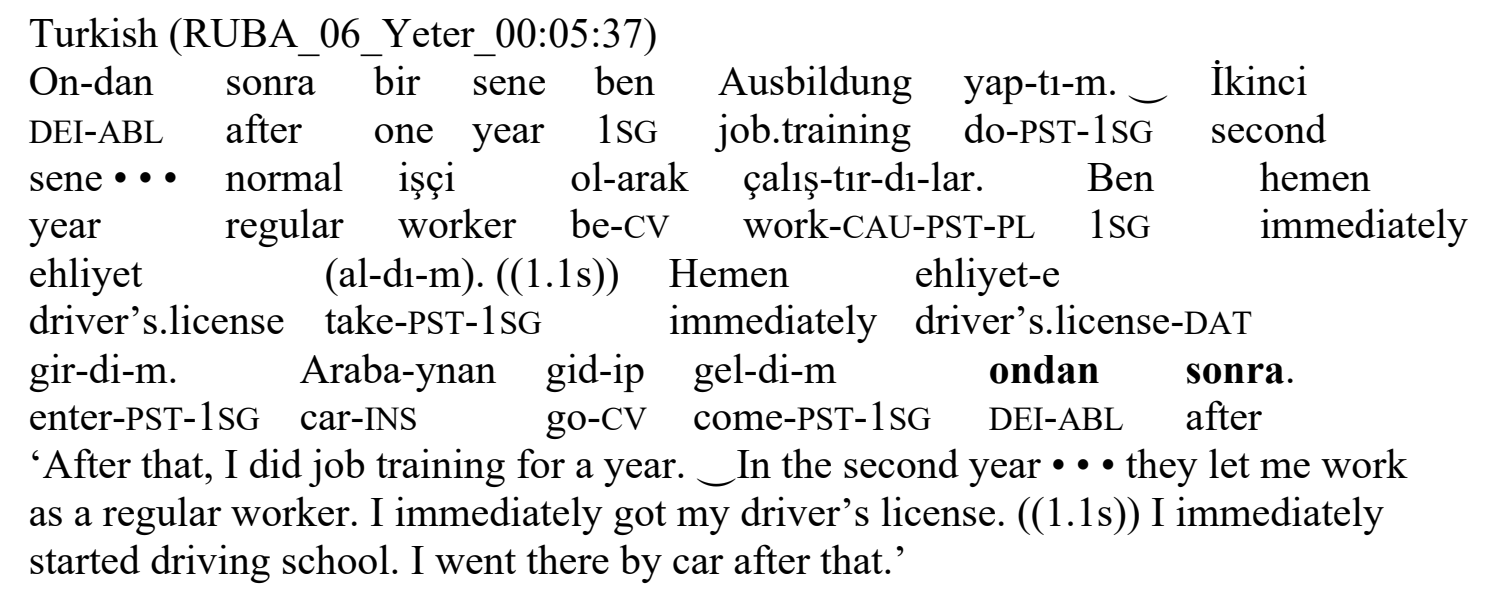

In (17), in German, Kerim talks about his and his sisters' second-language experience upon their arrival in Germany. At the time, the children are at primary school age, and they all struggle, however, Kerims elder sisters are having a harder time, which leads to their being downgraded, ending up in the same class with him. In 00:08:54, Kerim opens the topic of language difficulties, in 00:08:58, he brings the focus of attention to the classroom setting. Between 00:09:01 and 00:09:10, he provides background information about the age relationship between the siblings. Against this backdrop of activated information, the downgrading, when mentioned, already has a context, namely the class, however one whose activation may have been briefly interrupted; Kerim reactivates it in passing, in a post-predicate position (which in this case also is a postfield postition, after the participle): Die wurden 
aufgrund dieser • mangelnden Sprachkenntnisse natürlich zurückgestuft in der Klasse 'Due to this • lack of language skills, they were of course downgraded in class' (00:09:11).

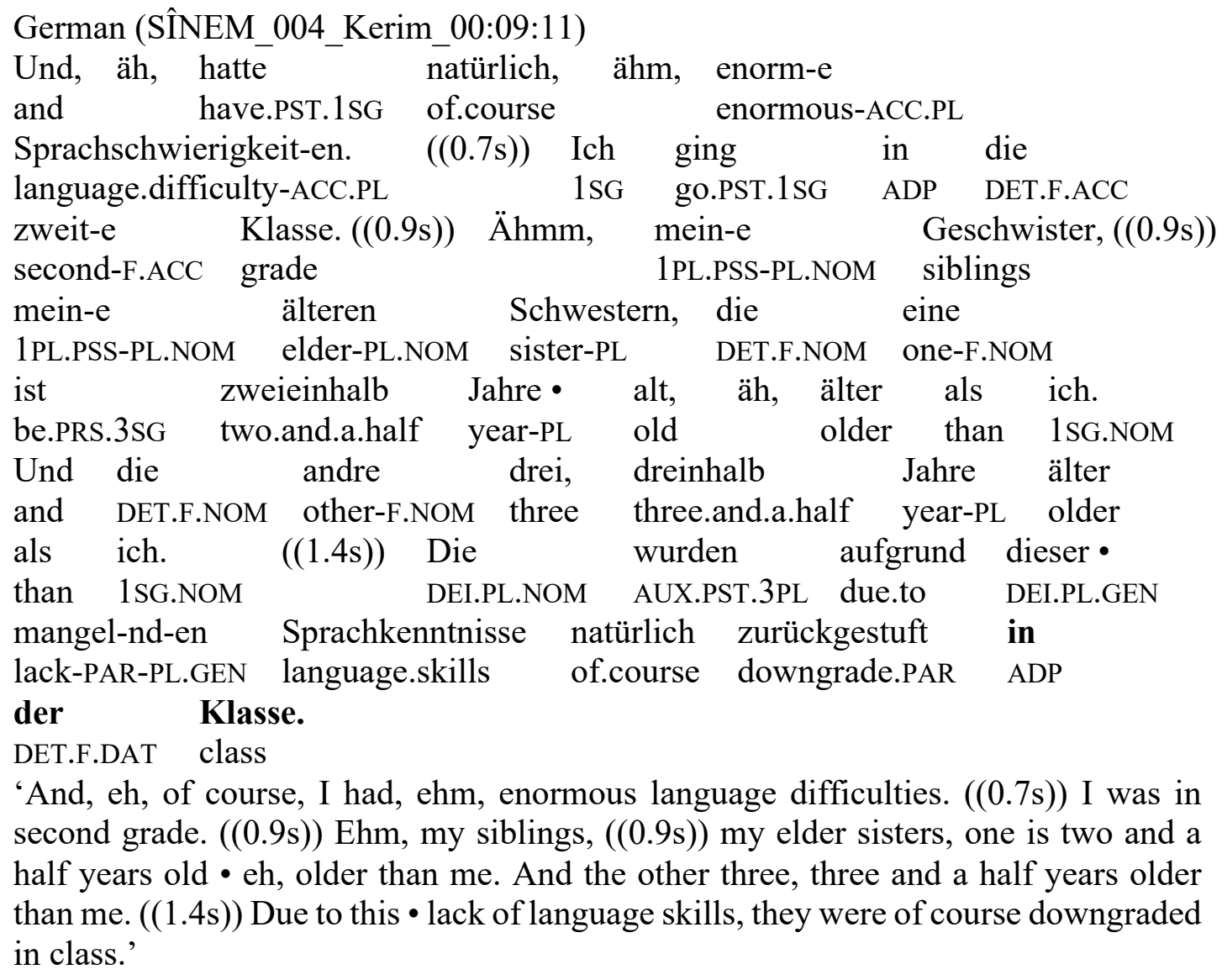

(18), in Kurdish, is a general remark about the unsatisfactory mother tongue situation at schools in the German state of Hessen, which puts Kurdish children's multilingual development at risk. In an afterthought, the speaker anchors his analysis in his personal experience as a father of two grown-up children:

$$
\begin{aligned}
& \text { Kurmanji (SÎNEM_003_Meded_00:10:02) } \\
& \text { Li.vêderê, ji.ber.ku }-{ }^{-} \text {bi ziman-ê zikmakî dibistan-a de } \\
& \text { here because ADP language-EZF.M native school-OBL.PL ADP } \\
& \text { ders-a kurdî nîne, ((1.3s)) hînbûn-a zarok-a • } \\
& \text { education-EZF.F Kurdish nonexistent learn.VN-EZF.F child-OBL.PL } \\
& \text { zimanê kurdî gelek zahmet e. Min bi xwe } \\
& \text { language-EZF.M Kurdish very difficult be.PRS.3SG 1SG.OBL ADP RFL } \\
& \text { - ee - dît, ji tecrûb-a min. } \\
& \text { see.PST.3SG ADP experience-EZF.F 1SG.OBL }
\end{aligned}
$$

6.2. REACTIVATION IN PASSING OF AGENTS OR EXPERIENCERS: SUBJECTS AND OBJECTS. The reactivation of referents that already form part of activated discourse knowledge can be said to be a prominent feature of Turkish: the data contain 92 findings. However, there are also five such findings in the Kurdish data - not many, but still worth looking at. In German, on the other hand, almost all postpredicative subjects and direct objects seem to be motivated by 
verb fronting. Example (19), in Turkish, provides the discourse context to (1) above: a group discussion of societal issues, taking place in a smokers' café. The active topic is an intergenerational comparison, while the first, second, and third generations can be regarded as its subtopics or specific strings. The third generation, in the speaker's impression, lives almost as separately from the general society as the first, whereas the second generation had gone through a phase of integration and had many international friends. In 00:02:39, the second generation is mentioned for the first time after the first and third generation have already been talked about: İkinci kuşăga baktı̆̆ımız zaman... 'When we look at the second generation...' In 00:02:42, the same NP re-occurs, now the subject of the main clause: ikinci kuşak $\cdots \cdot((n e f e s$ alır $))$ Almanların, • yabancıların içinde büyümüş 'the second generation - - ((takes a breath)) has grown up among the Germans, the - foreigners'. By the third time the second generation is referred to, it has become a well-estabished topic of conversation, however, since all three generations are being talked about in close succession, it may still require a bit of clarifying identification: $\operatorname{Çok}^{\prime} \bullet \iota \mathrm{h} \cdot \bullet$ mesela $\bullet$ yabancı arkadaşlarl olan bir toplum olmuş, $\bullet$ ikinci kuşak 'They have become a group that has $\bullet \cdot$ many $\bullet$ eh $\bullet \bullet$ for instance $\bullet$ foreign friends, $\bullet$ the second generation' (00:02:47). (19) thus illustrates the wellknown re-mentioning-in-passing of a pre-mentioned referent, in order to keep it activated in the shared discourse knowledge, on the margin of the focus of attention, but focused enough to keep it from being confounded with other active referents.

(19) Turkish (RUBA_01_Ahmet 00:02:47 Haluk)

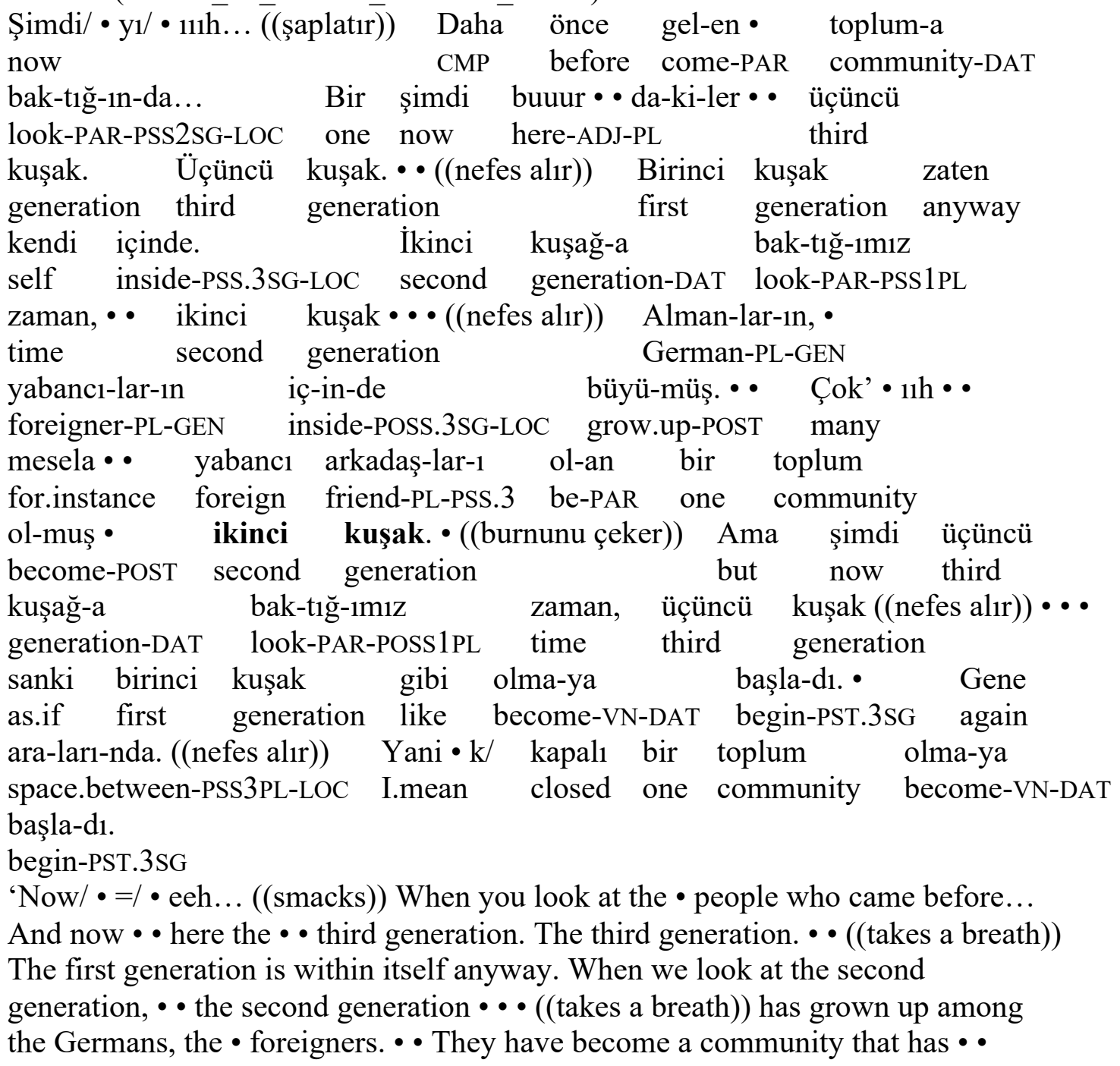


many $\bullet$ eh $\bullet$ for instance $\bullet$ foreign friends, $\bullet$ the second generation. $\bullet(($ sniffs $))$ But now when we look at the third generation, the third generation $(($ takes a breath $)) \bullet \bullet$ - it's as if it had started to become like the first generation. • They are among themselves again. ((takes a breath)) I mean, it has started to become a $\bullet$ closed community.'

As mentioned in 4.2, Turkish has the largest number of post-predicative subjects among the three languages. Slightly more than half of them are pronominal or deictic; one instance (biz 'we') could be seen at the beginning of (12) above (Ekmek bulamiyorduk biz 'bread findNEG.MOD-PRS-COP.PST.1PL 1PL', 'We couldn't find bread). As these small elements carry little information usable for the introduction of new referents, a typical use is for reactivation in passing, as the restaged or imagined piece of confrontative dialogue in (20), where the addressee of the question would have been present in the conversation:

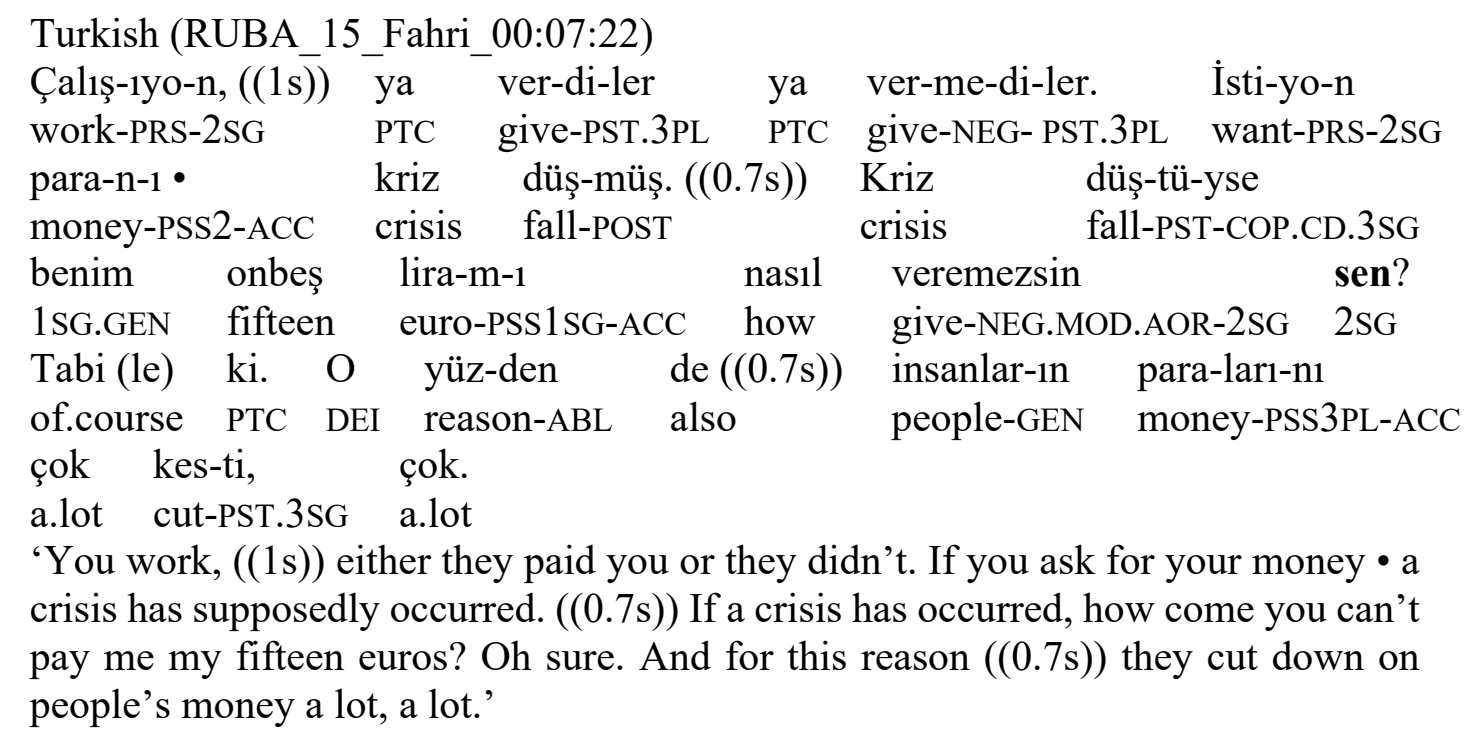

In the German data, there is only one occurrence of a postpredicative pronominal or deictic reeferent, and this example occurs in the data of an adulthood bilingual whose German can be assumed to be under Turkish influence; see the postpredicative speaker deixis in the short passage about a German exam in (21):

$$
\begin{aligned}
& \text { German (RUBA_04_Celal_00:24:36_Gülümser) } \\
& \text { Ooh, heute, das is } \cdots 111 \mathrm{~h} \text {, Prüfung schafft. }((0.8 \mathrm{~s})) \text { Ich. } \\
& \text { today DEI be.PRS.3SG exam succeed.PRS.3SG 1SG.NOM } \\
& \text { 'Oh, today I succeeded in my exam, I did.' }
\end{aligned}
$$

The Kurmanji data do not contain any pronominal or deictic subjects or objects in postpredicative position at all (other than wh or after 'say'). However, the occasional NP-size elements do occur. In (22), in Kurmanji, Mahir is talking about his children's Kurdish. The topic is introduced by the interviewer in a somewhat digressive way. In the passage preceding the example, she first asks about the children, then about their early childhood, their school, and about the situation of Kurdish at the time. After the activation of this panorama of topics, Mahir begins to talk about one little aspect, namely where the children were born in the first place. He does so in two takes: Du heb vira hatin dinê 'Two were born here', then, after a short break: Du heb li vir hatin dinê zarok'Two children were born here' (01:51:03). It seems that, in the given interactional situation, after the first take, he feels a need to reinforce, 
even in passing, what the actual topic now is, before moving on to other aspects of the situation.

(22) Kurmanji (SÎNEM_008_Mahir_01:51:03)

$\begin{array}{lllllll}\text { Du heb vira hatin } & \text { dinê. } \cdots & \text { Du } & \text { heb li } & \text { vir } \\ \text { two CLA } & \text { DEI come.PST-PL word-OBL.F two } & \text { CLA } & \text { ADP } & \text { DEI } \\ \text { hatin } & \text { dinê } & & & & \\ \text { come.PST-PL } & \text { word-OBL.F child } \\ \text { 'Two were born here. } ・-\text { Two children were born here.' } & & & \end{array}$

In (23), the scene of a university entrance exam is described, back in 1981. At the time, those exams took place in a school setting, and there was a requirement to wear ties. The speaker sketches the scene. After mentioning the tie, he gets back to this detail, adding the historical information about its obligatoriness, then reactivating the referent to which the added information is to be connected: qrawat 'tie'.

$$
\begin{aligned}
& \text { Kurmanji (SÎNEM_009_Sezgin_00:40:09) } \\
& \text { Heştî û yek. }((2 . \overline{6 s})) \text { Ewêt... • Ayni, ez li hem } \\
& \text { eighty and one same 1SG.RCT ADP also } \\
& \text { di (ruyê) dibîstan-ê hem di ro... } \cdots \text { Klas e, } \\
& \text { ADP ( ) school-OBL also ADP classroom be.PRS.3SG } \\
& \text { yanî em sinif } \bullet \quad \text { em } \quad \text { bêjin. } ・ \text { Klassenraum. ((1.3s)) } \\
& \text { PTC 1PL.RCT classroom 1PL.RCT SBJ.say.PRS.PL classroom } \\
& \text { Teblû, }((1.1 \mathrm{~s})) \quad \text { qrawat, }((0.6 \mathrm{~s})) \text { vî çaxî mecburî bû } \\
& \text { ( ) tie DEI.M.OBL period-OBL required be.PST.3SG } \\
& \text { qrawat. }((1.5 \mathrm{~s})) \quad \text { Tabî kiteb-ê me } \quad[\ldots] \\
& \text { tie of.course book-EZF.M 1PL.OBL } \\
& \text { 'Eighty-one. ((2.6s)) ( )... • Same, I ( ) both in the school and in... • It's a } \\
& \text { classroom, I mean, let's • say a classroom. • A classroom. }((1.3 \mathrm{~s}))(\quad \quad),((1.1 \mathrm{~s})) \\
& \text { tie, }((0.6 \mathrm{~s})) \text { at this period, it was required, a tie. }((1.5 \mathrm{~s})) \text { Of course, our book [...]' }
\end{aligned}
$$

(24) is about Turkish state-run boarding schools in which Kurdish children were taught to become Turks. While the speaker himself did not attend such a school, he does have some second-hand knowledge through acquaintances. The aim of such schools, he says, was to alter the children, and alter them it apparently did. The nominal zarok 'child', naming the experiencer of the procedure, occurs three times. The third time, it is so active in discourse knowlegdge that reactivation in passing seems sufficient to keep the reference clear.

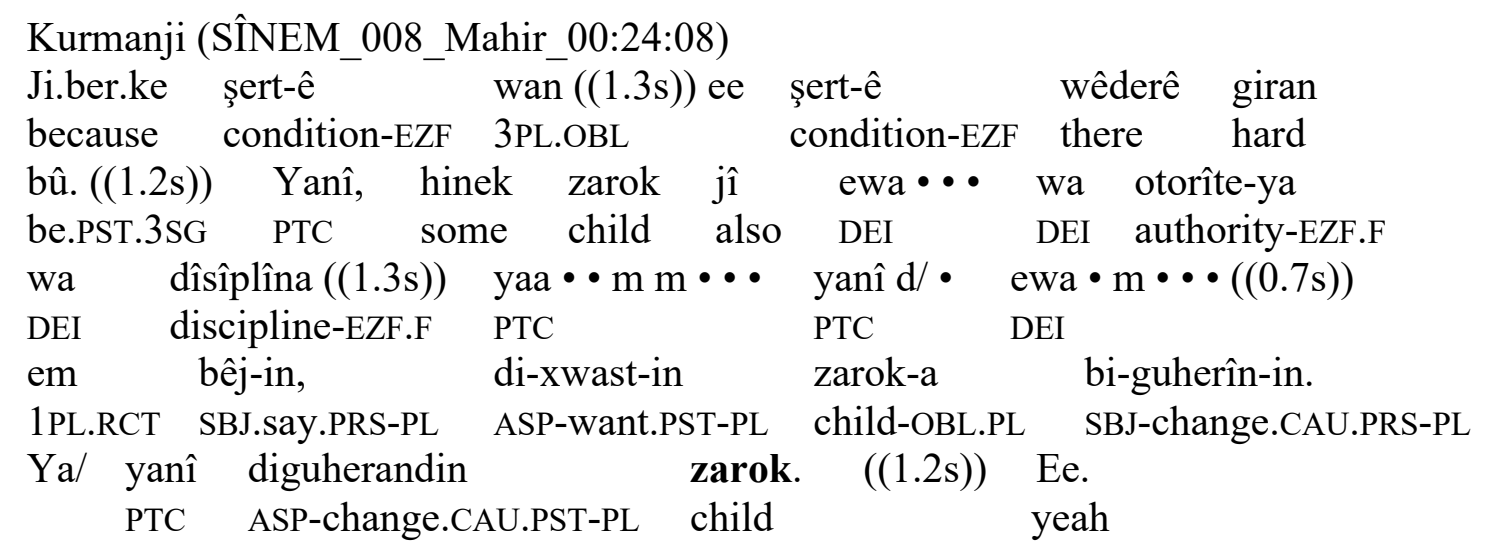


'Because the conditions of those $((1.3 \mathrm{~s}))$ eh the conditions there were hard. $((1.2 \mathrm{~s}))$ I mean, some children also those $\cdots$ that authority, that discipline $((1.3 \mathrm{~s}))$ well, $\cdots \mathrm{m} \mathrm{m} \cdots$ I mean ()$/ \bullet$ that $\bullet \mathrm{m} \cdots((0.7 \mathrm{~s}))$ let's say, they wanted to change the children. ( )/ I mean, they did change the children. ((1.2s)) Yeah.'

7. Conclusions: Towards an overview of overlaps. This study has looked at 1,211 findings of postpredicative elements in three languages, slightly over 400 for each. At the outset, expectations were that the epiphenomenon of postpredicativity might be roughly attributable to VP-level motivations in Kurmanji, IP-level motivations in German as well as partly in Turkish, and CP-level motivations in Turkish. Table 6 quantifies what has been found. At the VP level, next to semantic argument type, syntactic size of the arguments and semantic type of the predicate emerged as relevant, showing that non-goals in Kurmanji surface postpredicatively from VP-size onwards and that 'say' might have a head-initial government direction. At the IP level, verb fronting for inflectional and illocutional reasons was considered; illocutional analysis proved to overlap with discourse-level phenomena, often leading to inconclusive interpretations, in Turkish. In German, on the whole, most effects of postpredicativity can be attributed to verb fronting, i.e. the IP level, whereas in Kurmanji, the IP level seems to play no role at all. At the CP-level, finally, it was found that in Kurmanji, too, discourse-level phenomena may play a role, however, also somewhat depending on syntactic size (excluding pronominal and deictic elements), and on the whole less frequently than in Turkish, but more frequently than in German. On the whole, the three set of data conform to the initial assumptions at a rate of slightly over $73 \%$ in German, $80 \%$ in Kurmanji, and $90 \%$ in Turkish. The relatively large proportion of VP- and CP-level motivations in German come as no surprise. However, the 41 findings in Turkish for which some type of verb fronting seemed plausible, a somewhat prominent topic of discussion in the literature, make up for just $10 \%$ of the findings (41 in absolute figures) in this language, including findings with double or overlapping motivations. On the other hand, discourselevel motivations account for almost a fifth of the Kurmanji findings; these findings can be interpreted as really going beyond what Haig \& Rasekhmahand (2019: 5) refer to as 'the hard facts of syntax'.

\begin{tabular}{|c|c|c|c|c|c|c|c|c|}
\hline & & $\begin{array}{l}\text { Kurmanj } \\
\text { abs. }\end{array}$ & i & $\begin{array}{l}\text { German } \\
\text { abs. }\end{array}$ & $\%$ & $\begin{array}{l}\text { Turkish } \\
\text { abs. }\end{array}$ & $\%$ & $\begin{array}{l}\Sigma \\
\text { abs. }\end{array}$ \\
\hline \multirow[t]{6}{*}{ VP } & argument type: goal & 181 & 44.9 & ב- & - & - & - & 181 \\
\hline & argument size: VP, clause & 109 & 27.0 & 61 & 15.2 & - & - & 170 \\
\hline & argument type: numeral & - & - & - & - & 12 & 2.9 & 12 \\
\hline & argument type: verb in V-V-construction & - & - & - & - & 6 & 1.4 & 6 \\
\hline & predicate type 'say' & 35 & 8.6 & - & - & 3 & 0.7 & 38 \\
\hline & predicate type: lazım & - & - & - & - & 1 & 0.2 & 1 \\
\hline \multirow[t]{6}{*}{ IP } & fronting to second or initial position & - & - & 295 & 73.5 & - & - & 295 \\
\hline & fronted (caused) motion verb & - & - & - & - & 8 & 1.9 & 8 \\
\hline & fronted interrogative verb & - & - & - & - & 1 & 0.2 & 1 \\
\hline & fronted imperative verb & - & - & - & - & 1 & 0.2 & 1 \\
\hline & fronted emotional verb & - & - & - & - & 5 & 1.2 & 5 \\
\hline & fronted dynamic verb & - & - & - & - & 1 & 0.2 & 1 \\
\hline $\mathrm{IP} / \mathrm{CP}$ & fronted predicate and discourse activation & - & - & - & - & 25 & 6.1 & 25 \\
\hline $\mathrm{CP}$ & discourse activation status & 78 & 19.3 & 45 & 11.2 & 344 & 84.5 & 467 \\
\hline$\overline{\Sigma \Sigma}$ & & 403 & 100 & 401 & 100 & 407 & 100 & $\overline{11,211}$ \\
\hline
\end{tabular}

Table 6: Distribution of the three functional areas across the three languages

Similarly as the ongoing corpus building process, these results are preliminary and will need further investigation, especially in terms of discourse-pragmatic interpretation; this will require teamwork and discussion. While this paper did not pursue any explanatory goals to 
begin with, now that some of the descriptive goals have been more closely approached may be the point to start asking such questions anyway. One such question to ask then might be how to explain the variablity. Here, obviously, the multilingualism of speakers and communities comes to mind; some function that has been syntactically expressed in one language may come to be expressed by employing a similar pattern in another language of a speaker's repertoire. Speakers, communities, generations or even milieus might in this respect vary as much as language-biographical givens do. While this might not be exactly new, the way how precisely this happens in these specific data might be worth further exploration. One might also ask how the various functions of a syntactic pattern in a given language can be put in relation to each other, maybe also how to identify and describe a core function from which the other functions can be derived. These are questions that this paper has barely been able to ask and it would require a follow-up study to attempt find answers. - At the categorial level, future work might further take apart my makeshift concept of 'syntactic size' and relate parts of it to discussions going on elsewhere.

\section{Abbreviations}

1 first person

2 second person

3 third person

ABL ablative

ACC accusative

ADJ adjective

ADP adposition

AOR aorist

ASP aspect

AUX auxiliary verb

CAU causative

CLA classifier

CD conditional

CMP comparative

COP copula

$\mathrm{CV}$ converb

DAT dative

$\begin{array}{ll}\text { DEI } & \text { deixis } \\ \text { DER } & \text { derivation } \\ \text { DET } & \text { determiner } \\ \text { EVID } & \text { evidential/ indirective } \\ \text { EZF } & \text { ezafe } \\ \text { F } & \text { feminine } \\ \text { FUT } & \text { future } \\ \text { GEN } & \text { genitive } \\ \text { INDEF } & \text { indefinite } \\ \text { LOC } & \text { locative } \\ \text { M } & \text { masculine } \\ \text { MOD } & \text { modality } \\ \text { NEG } & \text { negation } \\ \text { NOM } & \text { nominative } \\ \text { OBL } & \text { oblique case } \\ \text { OPT } & \text { optative } \\ \text { PAR } & \text { participle }\end{array}$

$\begin{array}{ll}\text { PAS } & \text { passive } \\ \text { PL } & \text { plural } \\ \text { POL } & \text { politeness } \\ \text { POST } & \text { postterminal } \\ \text { PRS } & \text { present tense } \\ \text { PST } & \text { past tense } \\ \text { PSS } & \text { possessive } \\ \text { PTC } & \text { particle } \\ \text { Q } & \text { interrogativity } \\ \text { RCT } & \text { direct case } \\ \text { REC } & \text { reciprocal } \\ \text { RFL } & \text { reflexive } \\ \text { SBJ } & \text { subjunctive } \\ \text { SG } & \text { singular } \\ \text { SUP } & \text { superlative } \\ \text { VN } & \text { verbal noun }\end{array}$

\section{References}

Bainbridge, Margaret. 1972. Sequence in the syntactic structures of spoken Turkish. London: University of London (dissertation).

Chafe, Wallace. 1994. Discourse, consciousness, and time: The flow and displacement of conscious experience in speaking and writing. Chicago: Chicago UP.

Cinque, Guglielmo. 1999. Adverbs and Functional Heads: A Cross-Linguistic Perspective. Oxford: OUP.

Doğruöz, A. Seza \& Ad Backus. 2007. Postverbal elements in immigrant Turkish: Evidence of change? International Journal of Bilingualism 11(2). 185-220.

Dryer, Matthew S. 2013a. Order of subject, object and verb. In: Dryer, Matthew S. \& Haspelmath, Martin (eds.), The World Atlas of Language Structures Online. Leipzig: Max Planck Institute for Evolutionary Anthropology. Online: http://wals.info/chapter/81 (accessed on December 7, 2019).

Dryer, Matthew S. 2013b. Order of object and verb. In: Dryer, Matthew S. \& Haspelmath, Martin (eds.), The World Atlas of Language Structures Online. Leipzig: Max Planck Institute for Evolutionary Anthropology. Online: http://wals.info/chapter/83 (accessed on December 7, 2019). 
Dryer, Matthew S. \& Martin Haspelmath (eds.). 2013. The World Atlas of Language Structures Online. Leipzig: Max Planck Institute for Evolutionary Anthropology. Online: http://wals.info/chapter/84 (accessed on December 7, 2019).

Dryer, Matthew S. with Orin D. Gensler. 2013. Order of object, oblique, and verb. In: Dryer, Matthew S. \& Haspelmath, Martin (eds.), The World Atlas of Language Structures Online. Leipzig: Max Planck Institute for Evolutionary Anthropology. Online: http://wals.info/chapter/84 (accessed on December 7, 2019).

Erdal, Marcel. 1999. Das Nachfeld im Türkischen und im Deutschen [The postfield in Turkish and in German]. In: Johanson, Lars \& Rehbein, Jochen (eds.) Türkisch und Deutsch im Vergleich. 53-94. Wiesbaden: Harrassowitz (Turcologica 39).

Erguvanl, Eser Emine. 1984. The function of word order in Turkish Grammar. Berkeley: Univ. of California Press (University of California Publications in Linguistics 106).

Gündoğdu, Songül. 2019. Asymmetries in Kurmanji morphosyntax. In: Gündoğdu, Songül \& Öpengin, Ergin \& Haig, Geoffrey \& Anonby, Erik (eds.) Current issues in Kurdish linguistics. 93-116. Bamberg: University of Bamberg Press (Bamberg Studies in Kurdish Linguistics 1).

Haig, Geoffrey. 2014. Verb-Goal (VG) word order in Kurdish and Neo-Aramaic: Typological and areal considerations. In: Khan, Geoffrey \& Lidia Napiorkowska (eds.). Neo-Aramaic and its linguistic context. 407-425. New York: Gorgias Press.

Haig, Geoffrey \& Mohammad Rasekhmahand. 2019. Position paper for the project on Postpredicative constituents in Iranian and neighbouring languages. Unpblished ms.

Haig, Geoffrey \& Hanna Thiele. 2014. Post-predicate Goals in Northern Kurdish and neighbouring languages: a pilot study in quantitative areal linguistics. Presentation at the Second international Conference on Variation and Change in Kurdish, Mardin Artuklu University, Turkey, 8-9th October 2014.

Herkenrath, Annette. 2017. Informal language teaching: Multilingual conversations in Kurdish diaspora settings. In: Grond, Agnes \& Brizić, Katharina \& Osztovics, Christoph \& Schmidinger, Thomas \& Six-Hohenbalken, Maria (eds.), Sprache - Migration Zusammenhalt: Kurdisch und seine Diasporal Language - Migration - Cohesion: Kurdish and its Diaspora. Special issue of Wiener Jahrbuch für Kurdische Studien/ Vienna Yearbook on Kurdish Studies 5. 110-126.

Herkenrath, Annette. 2018a. Constructing ditransitivity in literary Kurmanji: Some fuzzy issues. In: Korn, Agnes \& Malchukov, Andrej (eds.), Ditransitive constructions in a cross-linguistic perspective. 95-118. Wiesbaden: Dr. Ludwig Reichert Verlag.

Herkenrath, Annette. 2018b. Speaker deixis, body, and context: The unfolding of languagebiographical memory in spoken Turkish. In: Csató, Éva Á. \& Parslow, Joakim \& Türker, Emel \& Wigen Einar (eds.), Building Bridges to Turkish: Essays in Honour of Bernt Brendemoen. 147-173. Wiesbaden: Harrassowitz (Turcologica 116).

Herkenrath, Annette. 2020. Turkish in Germany: An adult-state twice-told-tale approach to not-entirely-balanced childhood bilingualism. In: Bayram, Fatih (ed.), Studies in Turkish as a Heritage Language. Amsterdam: Benjamins (SiBiL Studies in Bilingualism 60), 231-263.

Herkenrath, Annette. in preparation a. HIAT transcriptions of the LiLaC Corpus/ LiLaC Korpüs'ün HIAT transkripsyonları. LiLaC project (2007-2010): 'Schreiben zwischen Sprachen und Kulturen: Ressourcen und Hemmnis der Integration/ Literacy between Languages and Cultures: Resources and obstacles for integration/ Diller İle Kültürler Arası Yazışma Projesi', supervised by Ludger Hoffmann, Uta Quasthoff and Michael Kastner, TU Dortmund, Institut für deutsche Sprache und Literatur und Institut für Psychologie. Unpublished data, Adam Mickiewicz University, Poznań. 
Herkenrath, Annette. in preparation b. RUBA: Ruhr Havzası'ndan Türkçe Bürokrasi Anlatıları/ Türkische Bürokratieerzählungen aus dem Ruhrgebiet/ Turkish Tales of Bureaucracy from the Ruhr Region. Unpublished data, Adam Mickiewicz University, Poznań.

Herkenrath, Annette. in preparation c. SÎNEM: Sohbetên li ser zimên/ Conversations about language. Unpublished pilot corpus in progress, Adam Mickiewicz University, Poznań.

Lewis, Geoffrey L. 1967. Turkish Grammar. Oxford: Oxford University Press.

Malchukov, Andrej \& Haspelmath, Martin \& Comrie, Bernhard. 2010. Ditransitive constructions: A typological overview. In: Malchukov, Andrej \& Haspelmath, Martin \& Comrie, Bernhard (eds.), Studies in Ditransitive Constructions: A Comparative Handbook. 1-64. Berlin: De Gruyter.

Matras, Yaron. 2009. Language Contact. Cambridge: CUP.

Meisel, Jürgen M. 2011. First and Second Language Acquisition: Parallels and Differences. Cambridge: CUP (Cambridge Textbooks in Linguistics).

Mundy, C. S. (1955). Turkish syntax as a system of qualification. Bulletin of the School of Oriental and African Studies 17(2): 279-305.

Rizzi, Luigi. 1997. The Fine Structure of the Left Periphery. In: Haegeman, Liliane (ed.), Elements of Grammar. 281-337. Dordrecht: Kluwer.

Rizzi, Luigi. 2004. On the Cartography of Syntactic Structures. In: Rizzi, Luigi (ed.), The Structure of CP and IP: The Cartography of Syntactic Structures, Volume 2. 3-15. Oxford: OUP (Oxford Studies in Comparative Syntax).

Schroeder, Christoph. 1995. Post-predicative arguments in Turkish. Sprachtypologie und Universalienforschung (STUF) 48(1/2). 204-218. 


\section{Appendix: Concordanced passages, overview with information on topics and linguistic biographies}

\begin{tabular}{|c|c|c|c|c|c|c|}
\hline Language & Code & $\min$ & Conversational topics & Speaker with language-biographical information & Findings & Examples \\
\hline \multirow[t]{4}{*}{ Turkish } & \multirow[t]{4}{*}{ "RUBA_01 } & \multirow[t]{4}{*}{32} & \multirow[t]{4}{*}{ group conversation on society, economy, family } & Ahmet, Kurmanji-Turkish-German (age of acquisition $>20$ ) & 9 & \\
\hline & & & & Haluk, Kurmanji-Turkish-German $(>30)$ & 29 & $1,15,19$ \\
\hline & & & & Haydar, Turkish-German $(>20)$ & 43 & 13 \\
\hline & & & & İbrahim, Kurmanji-Turkish-German (> 20) & 1 & \\
\hline Turkish & RUBA_02 & 38 & husband's accident, life in Germany, learning German & Ş̦engül, Turkish-German (> 25?) & 4 & \\
\hline \multirow[t]{3}{*}{ Turkish } & \multirow[t]{3}{*}{ RUBA_04 } & \multirow[t]{3}{*}{13} & \multirow[t]{3}{*}{ working childhood, village, German classes } & Celal, Kurmanji-Turkish $(>6)$-German $(>20)$ & 42 & \\
\hline & & & & Fikret, Kurmanji-Turkish $(>6)$-German $(>20)$ & 4 & \\
\hline & & & & Gülümser, Turkish-German $(>20)$ & 1 & 21 \\
\hline Turkish & RUBA_12 & 37 & society, young generation, job market discrimination & Arif, Turkish-German $(>30)$ & 57 & 11,12 \\
\hline \multirow[t]{2}{*}{ Turkish } & \multirow[t]{2}{*}{ RUBA_15 } & \multirow[t]{2}{*}{12} & \multirow[t]{2}{*}{ life and economic situation as an EU migrant } & Fahri, Turkish-Bulgarian & 43 & 20 \\
\hline & & & & Şükran, Turkish-Bulgarian & 1 & \\
\hline \multicolumn{2}{|l|}{$\sum$} & \multicolumn{2}{|l|}{161} & \multicolumn{2}{|r|}{407} & \\
\hline Kurmanji & " SîNEM_001 & 25 & sociolinguistic situation of Kurdish in various places & $\begin{array}{l}\text { Serko, Kurmanji-Turkish (> 6)-Arabic (> 6)-Zazaki-Sorani- } \\
\text { German }(>20-30)\end{array}$ & 64 & 2,5 \\
\hline Kurmanji & SÎNEM 002 & 18 & village, migration to city and to Germany, school, son & Veli, Kurmanji-Turkish (> 6)-German $(>20)$ & 59 & 10 \\
\hline Kurmanji & SÎNEM_003 & 18 & multilingual childhood, Kurds in Germany, cultural work & Meded, Zazaki-Kurmanji $(>8)$-Turkish $(>6)$-German $(>20)$ & 55 & 18 \\
\hline Kurmanji & SÎNEM_008 & 43 & youth in village and town, cultural work, children & Mahir, Kurmanji-Turkish-German (> 20) & 124 & $9,22,24$ \\
\hline Kurmanji & SÎNEM_009 & 9 & youth in Turkey & Sezgin, Kurmanji-Turkish-German $(>20)$ & 45 & 23 \\
\hline \multirow{2}{*}{ Kurmanji } & \multirow{2}{*}{ SÎNEM_010 } & \multirow{2}{*}{6} & \multirow{2}{*}{ history of Nusaybin/Nisêbîn (slide presentation) } & Veli, Kurmanji-Turkish $(>6)$-German $(>20)$ & 1 & \\
\hline & & & & Mahir, Kurmanji-Turkish-German $(>20)$ & 1 & \\
\hline \multirow[t]{2}{*}{ Kurmanji } & \multirow[t]{2}{*}{ SÎNEM_016 } & \multirow[t]{2}{*}{7} & \multirow[t]{2}{*}{ history of Kurdish migration to Germany (presentation) } & Meded, Zazaki-Kurmanji $(>8)$-Turkish $(>6)$-German $(>20)$ & 15 & \\
\hline & & & & Veli, Kurmanji-Turkish (> 6)-German $(>20)$ & 7 & \\
\hline Kurmanji & SÎNEM_021 & 3 & history of Kurdish classes in Germany (presentation) & Zanyar, Kurmanji-Turkish-German & 14 & \\
\hline$\underline{\underline{\Sigma}}$ & & 129 & & & 403 & \\
\hline German & RUBA_04 & 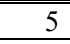 & German exam and class & "Gülümser, Turkish-German (> 20) & 7 & 21 \\
\hline German & SÎNEM_002 & 5 & village, migration to city and to Germany, school, son & Veli, Kurmanji-Turkish (> 6)-German $(>20)$ & 21 & \\
\hline German & SÎNEM_004 & 21 & childhood, university, language shift, cultural work & Kerim, Kurmanji-Turkish $(>6)$-German $(>8)$ & 151 & $3,6,7,17$ \\
\hline German & SÎNEM_005 & 3 & topic and language choice at beginning of interview & Fidan, Kurmanji-Turkish-German (> 16) & 23 & \\
\hline & & & & Anita, German-Turkish $(>20)$-Kurdish $(>30)$ & 33 & \\
\hline German & LiLaC Tal & 4 & bureaucracy and community work & Taliha, Turkish-German (>6) & 63 & \\
\hline German & LiLaC_Vey & 7 & hospital experience with little son & Veysi, Kurmanji-Turkish $(>6)$-German $(>6)$-Arabic $(>$ ?) & 99 & \\
\hline & & & & Anita, German-Turkish $(>20)$-Kurdish $(>30)$ & 4 & \\
\hline$\underline{\underline{\Sigma}}$ & & 45 & & & 401 & \\
\hline$\sum$ & & 335 & & & 1,211 & \\
\hline
\end{tabular}


